\title{
Linguistic and Neighbourhood Integration among Highly-skilled Migrants - A Quantitative Analysis Using the Example of Foreign University Staff Members in Aachen, Bonn and Cologne
}

\author{
Daniela Imani, Josef Nipper, Günter Thieme
}

\begin{abstract}
Integration issues among highly-skilled migrants were long considered rather irrelevant, a view being based on the image of a transnational, highly mobile elite that easily gets along at different workplaces during their respective duration of stay. Recent studies, however, indicate the heterogeneity of the group, for example with regard to vocational situation as well as migration trajectories. Accordingly, questions about their integration in the respective host society gain importance. Therefore, this article deals with integration processes of highly-skilled migrants in Germany. Based on a standardised survey $(n=553)$ of foreign academics at the universities in Aachen, Bonn and Cologne, we examine aspects of the cultural and social dimension of integration processes in this group. In order to operationalise cultural integration, we chose linguistic competence indicators and social integration is operationalised using variables related to neighbourhood relationships. The study was primarily conducted using a cluster analysis.

With regard to their linguistic skills, the respondents can be divided into five clusters. The members of the first two clusters assess their language proficiency as above the mean, while the members of the last two clusters assess their language skills as distinctly lower than average. With regard to neighbourhood relationships, we identified six clusters that again differ in the assessment of their neighbourhood contacts. However, no linear-hierarchical composition is apparent in the neighbourhood integration clusters as was for the linguistic clusters. Furthermore, we examined the reciprocal effects between linguistic competence and neighbourhood relationships and the influences of selected predictor variables on these two dimensions. There is a highly significant correlation between linguistic competence and the neighbourhood situation. The correlation between linguistic competence and neighbourhood situation and a series of predictor variables such as nationality, academic discipline, family and household structures and duration of stay is also highly significant. We can also assume that some of these correlations, such as the latter, are reciprocal.
\end{abstract}

Keywords: Highly-skilled migrants · Integration · Linguistic competence • Neighbourhood relationships $\cdot$ Cluster analysis 


\section{Epistemological interest and objectives}

International migration movements are among the most important sub-aspects of globalisation. Recently, highly-skilled migrants have been receiving growing attention. A significant percentage of this group consists of foreign academics who meet with great interest among the management of the universities due to the aspiration for internationalisation in the higher education sector.

Until only recently, the dominant opinion was that highly-skilled migrants could make their own way in the society of the host country due to their cultural and social capital and therefore required no orientation assistance in their new environment. For this reason, the integration of highly-skilled migrants in general and foreign academics in particular was long, in a way, a "blind spot" in municipal support when settling into their university city and was left more or less to coincidental private contacts. Only in recent years this group has received the necessary attention and both the universities and the administrations of the cities studied are becoming aware of the importance of the integration of international academics. In this respect, it is notable that the concern for international orientation is reflected in the positions of the Prorector for Public and International Relations at the University of Bonn and the Prorector for Academic Careers, Diversity and International Affairs at the University of Cologne, which are both found at the top management level (of these universities). This quasi institutional attention needs to be supplemented however on location because the cities and urban regions are the places in which actual decisions are taken on easing integration and in which integration is experienced (Hillmann 2010: 8).

Against this background, there is a distinct need for empirical research on the integration of highly-skilled migrants in the respective urban society. The vague term "integration" and its varying connotations must be divided into sub-aspects or sub-dimensions and be defined in order to provide an operational basis for indepth analysis. This study aims to contribute to this with a special focus on the significance of linguistic competence and the development of neighbourhood relationships and will present a few empirical analyses on the social and cultural integration of foreign academics. ${ }^{1}$ On principle, both quantitative and qualitative methods can be used when examining the integration of highly-skilled migrants in urban society. Within the context of this entire project, qualitative approaches were also the basis in some other articles (Föbker et al. 2011, 2014; Otto/Temme 2012; Otto et al. 2011). However, this paper presents the results of a quantitative method.

Here, we first pursue the question of whether clusters of foreign academics can be identified that differ from one another with regard to their cultural integration (represented by linguistic competence variables) or their social integration (represented by variables describing neighbourhood relationships and settling into the

1 Since very few empirical results exist on the integration of international academics, the theoretical and conceptual discussion chiefly refer to highly-skilled migrants in general and only in some cases explicitly to the group of foreign academics. 
neighbourhood). Further, it will be assessed how these clusters are structured. The types were formed using cluster analysis methods. Secondly, we attempt to verify correlations between both the cultural dimension of integration and the social dimension and a series of independent predictor variables. In particular, we examined personal, vocational and migration biography variables as influencing factors, but also analysed variables that assess the subjective experiences of the foreign academics in their respective urban environment.

\section{$2 \quad$ Highly-skilled migrants in Germany}

\subsection{The political and socio-economic debate}

For a long time, Germany has had, at best, an ambivalent relationship with its immigrants. This already began with the easily misunderstood or euphemistic term "guest workers" in the era of the recruitment agreements. The rather defensive attitude continued with the persistent claim that Germany is not an immigration country. As early as the 1970s, with almost four million persons of non-German nationality and a percentage of foreigners of over six percent of the total population of Germany, this claim was obviously already false. The figures by the Federal Statistical Office for the year 2012 account for approximately 16.3 million persons with a migration background among Germany's 81.9 million inhabitants or 20.0 percent of the total population (Statistisches Bundesamt 2013a: 31-32).

Near the end of the $20^{\text {th }}$ century, the looming lack of skilled workers intensified the debate over legally regulating labour migration. In particular, the introduction of a green card in 2000 was meant to eliminate the lack of workers in the information and telecommunications sector. After lengthy disputes, immigration was legally regulated and a compromise was found with the law that came into force in 2005 that was given the not exactly immigration-friendly name "Act for the Control and Restriction of Immigration and for the Regulation of the Residence and Integration of EU Citizens and Foreigners".

In industry circles in particular, the assessment that Germany attracts far too few qualified immigrants still prevails today (cf. e.g. Hinte/Zimmermann 2010). This position is based on the grounds that the consequences of demographic change are irrefutable, whereby from an economic standpoint it is argued mainly that the needs of the market, specifically for well-qualified workers, cannot be met by exhausting existing workforce potentials (female employment rate, Educational Offensive). Even if some do not want to admit it, Germany has been an immigration country for decades and will also be urgently dependent on attracting and embracing immigrants in future both for demographic and labour market policy reasons. 


\subsection{Determining factors of the immigration of foreign academics to Germany}

The transition to a knowledge society increasingly means that the transfer and the geographical concentration of economically relevant knowledge are the keys to future innovation and economic prosperity. The bearers of this knowledge are primarily persons with corresponding qualifications (Florida 2003: 7; Tremblay 2005: 197; Beaverstock 2005: 245). International academics have special status here since they, as "bearers of diverse knowledge resources and experience" (Jöns 2006a: 333) can provide "new stimuli for research and teaching" where they live (Jöns 2006a: 333). Therefore, today their immigration is considered a chief element of national and supranational development strategies (EC 2008: 10; Mahroum 2000b: 373).

In the competition for the best talent, Germany is increasingly making an effort to present itself as an appealing research location in order to increase its competitiveness as a science and business location. We examine a positive development in the number of foreign members of academic staff at German institutions of tertiary education: between 2006 and 2011, the numbers rose by 13,424 persons (+61.4 percent) to 35,291 . At present 10.0 percent of all academic staff is made up of academics from over 150 different countries of origin (Statistisches Bundesamt 2007: 38, 2013b: 29).

A corresponding promotional infrastructure and the availability of resources, for example through the funding programmes of scientific organisations, are a chief factor here (DAAD 2012: 70). The elimination of impediments to mobility by means of legal frameworks is no less important. While most EU citizens can work and settle within the European Union without restrictions, this does not apply to citizens from third countries (Braun/Recchi 2008: 161-162; Guth 2007: 2). The implementation of the EU Researcher Directive and the EU Blue Card are thus meant to ease the hiring of highly-skilled third country nationals and make Germany more appealing as an immigration destination for top staff. The latter also enables third country nationals to receive an unlimited settlement permit under specific conditions (BMI 2012: 91; BAMF 2012).

The universities are also increasingly engaging in global competition for international academics and students. For example, the number of strategically developed international partnerships between universities and the number of internationally compatible courses of studies are increasing (Föbker et al. 2010: 65; Tremblay 2005: 197). Furthermore, some universities have developed special facilities for recruiting and supporting foreign academics and students (Alexander von Humboldt-Stiftung 2012). In line with the great diversity of the durations of stay, the programmes aim both to support persons with both short-term and longer term stays (Bauder 2012: 5). The programmes range from offers to get to know people, to help with bureaucratic hurdles, to support in the search for housing, schools for children or employment opportunities for accompanying partners (Föbker et al. 2010).

Yet it is not only from a social policy and economic perspective, but also from the viewpoint of students and academics themselves that stays abroad are increasingly becoming a natural and necessary element of academic education and career 
development (Ackers 2010: 85; Bauder 2012: 5; Mahroum 2000a: 26). The decision for or against a stay abroad and its progression are influenced by a set of structural and personal factors. In addition to institutionalised funding options and legal framework conditions (see above), these include in particular the availability of a diverse array of personal resources (Jöns 2006a: 346), one's personal situation and familial context (cf. e.g. Ackers 2010; Föbker et al. 2014; Guth 2007; Hardill 1998). Depending on the form and interrelation of these factors, the possibilities and the motivation for international mobility vary. The resulting mobility patterns differ, for example with regard to the origin and destination regions, the career phase or the duration of stay (Jöns 2006a/b; cf. also Mahroum 2000a/b; Otto/Temme 2012). The latter can be highly variable - depending on individual and structural framework conditions - and range from brief stays lasting only a few days to a number of years or life-long stays (Bauder 2012: 3; Ackers 2010: 84). Satisfaction with the new environment plays a prominent role when deciding how long to stay (Otto/Temme 2012: 74-75; Föbker et al. 2011: 353).

\section{The integration of highly-skilled migrants}

\subsection{Changes in forms of migration}

International migration was long understood as a basically permanent shift of one's place of residence to the destination or host country. This understanding was also the basis of the classical explanatory approaches of international migrations (cf. e.g. Massey et al. 1993). In recent decades, the general trends of globalisation with a growing economic interweaving even of distanced regions have brought about new forms of migration, which differ in part considerably from conventional migration types (cf. e.g. Gans 2011: 118; Hillmann 2010: 6-7).

Variations on circular migration have experienced a renaissance lately (Fassmann 2008). These forms of migration are of considerable relevance, in particular for highly-skilled migrants. This refers both to so-called expatriates, usually highly qualified employees of multinational corporations who take on a position abroad for a limited time, usually 1-3 years (cf. e.g. Cohen 1977; Beaverstock 2005; Findlay 1995; Meier 2009), and academics, as those studied in this article, who can be mobile for their careers and thus come under the category of circular migration (cf. e.g. Ackers 2010; Todisco et al. 2003; Bauder 2012; Föbker et al. 2011). This also applies to foreign students (Tremblay 2005).

This change in forms of migration results in altered conditions for integration in the host society. In addition to the previously dominant idea of long-term, gradual integration of immigrants in the society of the host country, today there are increased questions about "temporary integration." The terms transnationalism and transmigration also indicate that in times of globalisation, immigrants increasingly maintain close contact with earlier stations of their migration biographies. Thus, through simultaneous inclusion in various societies, such as the origin and host society, they create new, pluri-local social spaces that are independent of national 
borders and thus transnational and can develop their own transcultural identity with specific practices of daily life and symbolic systems (Pries 2001: 49-52; Glorius 2006: 141-142, 2007: 2-4).

\subsection{Integration of highly-skilled migrants}

Most European studies on the integration of immigrants refer to the integration of the earlier "guest workers" and their families. Differentiated according to various dimensions of integration - for instance structurally with regard to the work and residential situation, socially with regard to the development of social relationships in the host society and culturally with regard to the acquisition of specific knowledge and skills such as the language - they examine the phases, successes and impediments to the integration of these mostly blue-collar immigrants (cf. e.g. Gestring et al. 2006). By contrast, the discourse about the social and cultural consequences of the immigration of the highly qualified has only begun recently. For a long time, their reception in various spheres of urban society was not perceived as a problem either by academia or by politics and examination of the integration processes of this group was considered largely irrelevant (Kolb 2006: 169; White 1988: 411). This was based on the grounds that highly-skilled migrants frequently had temporary stays. However, in the previous section, we demonstrated that the durations of stay of the academics focussed on here are quite diverse so that examining their integration processes appears relevant.

\subsubsection{Structural dimensions of integration - labour market and residential situation}

The perception of highly qualified as immigrants who can become integrated in an urban society with comparative ease is also based on the focus on those immigrants who migrate according to their qualifications for an actual employment relationship (Findlay 1995: 515). This applies both to the studies on the international mobility of expatriates and to the foreign academics in Germany examined here. Since these are largely high-ranking positions with corresponding income, this group of the highly qualified appears to be a transnational elite (Beaverstock 2005) that differs distinctly in their social situation from traditional immigrant groups and is not perceived as a "problem group" with regard to structural integration in the labour market (Glebe 1997: 406). Nevertheless, some authors point out that this portrayal of a putative elite status of foreign highly qualified people does not do justice to the heterogeneity of this group (Favell et al. 2006: 2; Conradson/Latham 2005: 289-290). For instance, in most countries, only a minority of these academics have permanent employment contracts. Young academics in particular are commonly temporarily employed and their continued employment is often uncertain (Föbker et al. 2010: 65; cf. also Todisco et al. 2003: 125). The independent search for a (new) adequate position in the host society can prove difficult, for example due to labour laws, linguistic difficulties, prejudices to the employment of foreigners and a lack of 
networks (Voswinkel/Kontos 2010; Braun/Recchi 2008: 161). ${ }^{2}$ We can assume that this relatively uncertain longer-term structural integration can influence the entire integration process - in particular among labour immigrants from third countries whose residence permits are usually tied to a specific employment contract (BMJ 2012).

The residential situation of highly-skilled migrants was also hardly expounded on for a long time (Glebe 1986: 460). This group was perceived as a transnational elite, linked to the idea that they - due to their above-average socio-economic resources and high social acceptance among the host population - possess "practically unlimited access to the sectors of the housing market they prefer" (Glebe 1997: 410). This is accompanied by the fact that some of the highly qualified are given support in the search for a residence by their employers (Glebe 1997: 410; White 1988: 415-416).

Actually, studies on living locations of high-status immigrants ${ }^{3}$ in European cities ascertain a partly distinct spatial concentration of this group in upmarket residential areas of the city or, depending on their family phase, the suburbs (Scott 2006: 1117-1119; Glebe 1997: 410-411; Freund 2000: 94-95). The geographic distribution according to socio-economic factors is in some cities overlaid with a geographic distribution according to ethnic variables (Glebe 1986, 1997; Freund 2000; White/ Hurdley 2003). Frequently, these residential areas are characterised by a good international or ethnic infrastructure - ranging from specialities shops and medical services to associations, schools and kindergartens. These "expat enclaves" are appealing residential locations for the highly qualified and their employers because they can ease rapid settling in (White/Hurdley 2003: 694-696; White 1988: 419-420; cf. also Willis/Yeoh 2002: 558). However, not all highly-skilled migrants can or wish to live in such high-status neighbourhoods with a large number of other international highly qualified people. For instance, Scott (2006) indicates the increasing significance of a transnational middle class, to which most of the foreign academics studied here can also be allocated. With regard to their professional biographies and resources and thus also their residential situation, they differ in part greatly from high-income transnational professionals (Scott 2006: 1120; cf. also /lyes 2006: $6-7)$. Due to their lesser financial resources, they require less expensive living space in less high-status residential areas, which is quite positively assessed by some of the highly qualified since it can ease the development of local contacts outside the expat community (Thang et al. 2002: 546). It is, however, also possible that linguistic and cultural differences are more obvious in less cosmopolitan neighbourhoods

2 This problem also affects the accompanying partners who often, at least at first, cannot or are not permitted to pursue employment for the above reasons (Pethe 2006: 91, 133; Hardill 1998: 266). Föbker et al. (2014) point out that this in some cases can have very negative effects on well-being and intentions to stay.

3 Since most countries do not have precise data about the residential locations of highly-skilled migrants, some authors instead make use of data on the geographical distribution of selected nationalities (e.g. USA, Japan or western European countries) in a city. In doing so, they assume overall that members of these nationalities are largely highly qualified and have high-ranking employment (Glebe 1997: 407; White 1988: 411). 
and therefore impeding the development of social contacts and settling in (Föbker et al. 2014).

\subsubsection{The cultural dimension of integration - linguistic competence and settling in}

Generally, proficiency in the respective national language is considered the central prerequisite for integration in relevant spheres of the host society. Accordingly, enhancing the language skills of immigrants is a central element of German integration policies (Vogel/Rinke 2008: 261).

According to Esser (2006: 11) language has three functions in integration. Language skills are firstly a resource; learning a language can thus be seen as an investment in the human capital of the stakeholders. Furthermore, language has symbolic functions, since it "describes things, expresses inner conditions, transports demands and can 'define' situations (about them), including the activation of stereotypes about the speaker with any associated discriminations, for example through an accent" (Esser 2006: 11). Finally, as a medium of communication, language has the function of coordination and understanding. Language skills are thus an expression of cultural integration (Vogel/Rinke 2008: 265). At the same time, via these functions language skills are closely correlated to the progression of structural and social integration in essential areas of the respective host society (Esser 2006: 8).

The great importance given to linguistic competence for the integration of immigrants is also reflected in numerous empirical studies on the subject. In his summary of numerous quantitative studies on the correlation between language and integration, Esser (2006) cites central conditions for language acquisition including, in particular, aspects of the family and migration biography. A higher level of education, a longer duration of stay and more frequent stays can promote immigrants' acquisition of a second language. On the other hand, a higher age on arrival and low intentions to stay can have negative impacts on the competent acquisition of a second language (Esser 2006: 23-24). Furthermore, some aspects of the origin and destination context play important roles (Portes/Böröcz 1989). It is significant, for example with regard to the destination context, that the experience of discrimination can have negative effects on the motivation to acquire the second language (van Tubergen/Kalmijn 2005: 1442; cf. also Espenshade/Fu 1997: 288). With regard to the significance of cultural or social distances between the origin and host society, there are not yet reliable results. However, the influence of the linguistic distance between the languages of the origin and of the host country on learning the second language has been empirically proven (Esser 2006: 25-27), although these results refer to more traditional groups of immigrants. On the other hand, there are only a few findings about language acquisition and the importance of language for the integration process of highly-skilled migrants.

Whether and how well the language of the host country is learned is closely correlated with the planned duration of stay. If a temporary stay is planned from the outset, many highly qualified persons do not go to the trouble of learning the new language, not least due to intense workloads, and in particular when no future 
benefit can be drawn from investment in language skills (Nowicka 2006: 194; Föbker et al. 2011: 350, 352). However, the extent to which one can do without learning the national language depends highly on whether sound knowledge of the national language is necessary for exercising one's vocation and managing daily life. Immigrants can be confronted with quite different demands and expectations depending on their circumstances (Vogel/Rinke 2008:264).

Some authors point out that since English is the lingua franca in many international corporations and academic institutions, many highly qualified people do not require sound knowledge of the respective national language in their vocations and therefore do not need to learn it (Hillier 2007: 35-36; Thang et al. 2002: 547). The results of a study by the Federal Office for Migration and Refugees on the immigration of highly qualified workers from third countries (Hess 2009) show, however, that this applies only with reservations. Although approximately half of the surveyed highlyskilled migrants said that they did not require good or any German skills to practice their profession, the other half of the respondents need at least good, and even 30 percent of them very good German skills (Hess 2009: 40-41). Also with regard to the academics focussed on in this study, we can assume that the working language in many natural sciences is increasingly English. Thus, the academics in these fields are less dependent on skills in the respective national language than for example in the humanities or legal sciences (Jöns 2006b: 154). However, this applies in particular for those countries, in which broad parts of the population possess good English skills, such as the Netherlands and Finland, and less for those countries, where this is not the case such as Germany and France (EP 2009: 16) and where at many universities most courses, meetings, etc. continue to be conducted in the respective national language (Otto/Temme 2012: 90). In these countries, poorer language skills or even speaking with an accent can lead to exclusion and discrimination (Föbker et al. 2011: 357; Vogel/Rinke 2008: 264).

We can assume that these differences exist, however, not only at the national level, but, due to location (e.g. in border areas), immigration history, economic and population structures, also at the regional level. We therefore assume that communication in many relevant daily spheres - e.g. in contacts with the local population, while shopping, when using public transport or dealing with public authorities without exhaustive knowledge of the national language is easier in large international cities than in small towns without much experience with internationalisation. However, this correlation surely depends on the frequency and the quality of contacts. While communication is possible without or with less knowledge of the national language in less complex situations, it becomes more difficult with increasing complexity of the issue being communicated (Vogel/Rinke 2008: 264). Therefore, highly-skilled migrants who wish to or must develop more intense social contacts in the host society require knowledge of the national language more than persons for whom this is not the case (Thang et al. 2002: 547). However, good language skills are no guarantee for the establishment of such contacts since they can hardly compensate for a lack of interest of the host society (Föbker et al. 2014). Language is therefore a necessary but not always sufficient qualification for success in a new environment both for structural and social integration (Vogel/Rinke 2008: 275). 


\subsubsection{The social dimension of integration - neighbourhood relationships and settling in}

The question of social integration, in other words the development of social contacts and relationships in the host society, is directly related to the above remarks. In what contexts do social relationships develop and what significance do they have for settling in?

According to Grossetti (2005: 291-293), social relationships develop in only the rarest of cases based on fleeting, coincidental encounters. Rather the family or friends, work environment or the neighbourhood are the basis for the development of personal relationships. For the highly-skilled migrants focused on here, in particular the work environment appears to be the sphere in which they tend to make social contacts (Pethe 2006: 133; Otto/Temme 2012: 89-90). The mutual work and similar vocational interests, long work hours and low language barriers can ease the development of social contacts as compared to persons outside of the work environment (Guth 2007: 2). Often, the local social networks of highly-skilled migrants, at least at first, almost exclusively include work colleagues. In many internationalised work contexts, as those of these academics, this can mean that their social contacts are made up largely of international highly qualified persons with whom they spend their working as well as leisure time. Therefore, this can lead to social integration in a specific sphere of the host society - a transnational expat community - that has hardly any contacts with the autochthonous population. By contrast, many international academics also attempt to not focus too much on the traditional expat communities and to make social contacts with the local host society (Cohen 1977: 46-47; Coles 2008: 132; Thang et al. 2002: 547; Beaverstock 2005: 261). Often this is difficult due to linguistic and cultural differences as well as low interest on the part of the host society (Föbker et al. 2014).

Against this background and with regard to the social integration of highly-skilled migrants, it appears especially interesting to examine whether local networks are developed beyond the work environment and to what extent. At the beginning of the section, we noted the significance of neighbourhoods for the development of social networks (Grossetti 2005). Yet, it is also interesting to examine social integration from the angle of neighbourhood relationships since we can assume that - unlike, for example, membership in clubs - the overwhelming majority of highlyskilled migrants live within a neighbourhood and that more contact opportunities with the autochthonous population arise in the environment of the neighbourhood than in the quite specifically structured university work environment.

But what role do neighbourhood relationships play in the settling in of highlyskilled migrants? There are very few empirical studies that have taken up this subject matter, although the social significance of neighbourhoods has repeatedly been ardently discussed in recent years (cf. e.g. Forrest 2008; Forrest/Kearns 2001; Kearns/ Parkinson 2001). On the one hand, they point out that neighbourhood contacts, in particular in big cities, are increasingly losing significance for many people in their daily life because increased mobility and modern information and communication technologies offer far more opportunities today to maintain social contacts inde- 
pendently from local placing (Forrest/Kearns 2001: 2126). Today more than ever, the establishment and maintenance of neighbourhood contacts is merely one way of gaining access to social contacts (Fischer 1982: 98, 103; Guest/Wierzbicki 1999: 97).

On the other hand, however, neighbourhood relationships, in spite of the developments of recent years, are still an essential element of social contacts for many people (Gues/Wierzbicki 1999: 108-109). Although Henning and Lieberg (1996: 22) point out that these are in most cases rather superficial relationships, whose maintenance is important in particular for the organisation of everyday life (e.g. looking after the dwelling during longer absences, cf. also Fischer 1982: 132), these relationships have nevertheless relatively high status for feeling comfortable in the living environment.

Still, the status of neighbourhood relationships for individuals depend largely on their respective socio-economic situation and phase of life. For instance, for employed persons, we can assume that neighbourhood contacts have comparatively low significance since, unless they work from home, they spend little time there and also have easy and diverse possibilities to establish social networks through their work environment (Henning/Lieberg 1996: 22-23; Fischer 1982: 97). We also assume that this applies to the highly-skilled migrants focused on here, particularly since many of them have the opportunity to make contacts in different workplaces and establish transnational networks from these due to their greater geographic mobility (Mau/Mewes 2008: 265-266).

Nevertheless, neighbourhood relationships are particularly important for people who spend a lot of time at home and in their neighbourhood (Forrest/Kearns 2001: 2132; Fischer 1982: 98, 102). In the case of highly-skilled migrants, this applies primarily to the often non-employed accompanying partners (Pethe 2006: 91, 133; Hardill 1998: 266; Föbker et al. 2014) and their children. Unlike their working partners, they have fewer opportunities to establish social networks beyond their living environment so we can assume they give higher status to neighbourhood relationships. Often new neighbourhood contacts for adults arise from their children's "play contacts", schools or childcare facilities (Coles 2008: 133; Föbker et al. 2014). While the establishment of neighbourhood contacts in the so-called expat enclaves appears unproblematic (see above), outside of them language and cultural differences can impede sometimes very sought-after neighbourhood relationships (Föbker et al. 2014). Obviously, this can have a distinct impact on the well-being on location.

Generally, we can say that integration processes of highly-skilled migrants have increasingly been the focus of scientific studies in recent years. Previous findings on the integration processes of highly-skilled migrants are diverse if not contradictory not least due to the heterogeneity of this group. It appears a promising possibility to operationalise the cultural and social dimensions of integration based on an extensive random sample of the group of foreign academics at three large German universities and to examine them using the multivariate method of cluster analysis. 


\section{$4 \quad$ Project implementation and methodology}

\subsection{Project implementation and sample description}

The results portrayed in the following are based on a pilot study funded by the DFG, ${ }^{4}$ which was conducted in the years 2009 and 2010 in a joint project by the Geographical Institutes in Aachen, Bonn and Cologne. It focused on questions about the integration of foreign academics in the respective urban society. The study conducted both qualitative surveys through problem-centred interviews and quantitative surveys through a standardised survey (in German and English). For the latter, all foreign academic employees of the universities in Aachen, Bonn and Cologne (a total of 1,820 persons) received a standardised questionnaire. The response rate was 29 percent (Cologne), 32 percent (Aachen) and 35 percent (Bonn). This results in a sample size of 553 respondents, on which the analysis is based.

Tab. 1: Sample variables

\begin{tabular}{lccc}
\hline Gender $(\mathrm{n}=550)$ & in $\%$ & Origin by world regions $(\mathrm{n}=524)$ & in \% \\
Female & 40 & Europe (western) & 38.5 \\
Male & 60 & Europe (formerly socialistic) & 19.5 \\
Age $(\mathrm{n}=547)$ & Mean value & Predominantly Islamic countries & 11.1 \\
& 34.2 & East Asia & 12.8 \\
Duration of employment in years $(\mathrm{n}=547)$ & in $\%$ & South Asia & 8.6 \\
Less than 1 & 28.5 & Sub-Saharan Africa & 2.5 \\
1 to less than 3 & 33.8 & Latin America & 4.4 \\
3 to less than 5 & 17.4 & North America and Australia & 2.7 \\
5 to less than 10 & 11.7 & Discipline $(\mathrm{n}=430)$ & in $\%$ \\
10 and more & 8.6 & Natural sciences & 40.9 \\
Employment status $(\mathrm{n}=533)$ & in $\%$ & Humanities & 13.5 \\
Temporary & 84.8 & Medicine & 20.2 \\
Permanent & 15.2 & Engineering & 25.3 \\
\hline
\end{tabular}

Source: Authors' calculations

Table 1 summarises some of the variables of the sample that are relevant for this article. About 60 percent of the respondents are men. This reflects the unbalanced gender ratio at the three universities. The average age of the respondents is 34 years old. Over half of the respondents have worked for less than three years at their present university, almost 30 percent even less than one year. The disproportionately high short-term nature of employment is also revealed in the temporary contracts of 85 percent of the respondents. In order to describe the origin of

4 We would like to thank the Deutsche Forschungsgemeinschaft (German Research Foundation) for its financial support for the project. 
the respondents the spectrum of nationalities was summarised in world regions. ${ }^{5}$ The two largest groups come from Europe. The third largest group is made up of employees from East Asia with 13 percent. ${ }^{6}$ Finally, Table 1 summarises the most frequent responses on academic disciplines: approximately 40 percent of the respondents work in the natural sciences, approximately one fourth in engineering. Far fewer respondents cite that they work for an institute in the fields of the humanities (13.5 percent).

\subsection{General considerations about surveying integration information}

The questionnaire contained a self-assessment of settling into urban society using the following two dimensions: competence in the German language and life in the neighbourhood. For linguistic competence, four aspects of linguistic skills were differentiated: speaking, listening comprehension, reading comprehension and writing ability. The respondents were able to make their assessments based on the following assessment key (German skills in...): very good (1), good (2), fair (3), a little (4), not at all (5).

For the life in the neighbourhood, the respondents were given seven statements:

- I have contact with many people living in my neighbourhood. (= many contacts)

- I hardly know anyone in my neighbourhood. (= acquainted with neighbours)

- I often have longer conversations with some neighbours. (= converse with neighbours)

- I greet the neighbours, but have hardly any contact otherwise. (= greet the neighbours)

- I do not know who lives in my neighbourhood. (= recognise neighbours)

- I know some of my neighbours so well that we extend reciprocal invitations. (= invite neighbours)

- My neighbours help me when I ask. (= help from neighbours)

The respondents were asked to classify these statements according to the following four responses: strongly agree, agree, disagree, and strongly disagree. With regard to the ensuing evaluations, the assessment scale for all seven aspects was coded with the numbers 1, 2, 3 and 4 whereby 1 always represented the highest

5 The countries of origin of the respondents were divided up into the following regional categories, whereby cultural aspects (linguistic, religious and ethnic) played a particular role in creating the categories: Europe (western), Europe (formerly socialistic), predominantly Islamic countries, Sub-Saharan Africa, South Asia, East Asia, Latin America, North America and Australia.

6 This distribution (for the three universities) corresponds roughly to the national values where employees from European ( 63 percent) and Asian ( 23 percent) countries are most frequently represented. Only between four and five percent come from Great Britain and the USA, the internationally leading science centres and favoured destinations of German academics abroad (Statistisches Bundesamt 2013b: 191-194). 
degree of integration in the neighbourhood and 4 the lowest. Hence, for acquainted with neighbours, a 4 was coded when someone strongly agreed with the statement (and therefore hardly knows anyone in the neighbourhood) and those who disagreed received a 1.

The settling in of the foreign university employees is compiled and characterised in three analysis steps for the two dimensions based on the listed aspects. First, a general description is provided using statistical parameters. Then, based on a cluster analysis, clusters of respondents are extracted for the two dimensions whose assessments are similar for the four or seven aspects and who are therefore similarly structured with regard to the two dimensions of settling in. In the third step, interrelations between these clusters and potentially influencing variables, for example nationality, discipline, duration of stay, are revealed or verified.

\subsection{Methodology (cluster analysis and contingency analysis)}

Clusters of respondents with similar assessments for the two dimensions of settling in are extracted using cluster analyses. This approach can sufficiently fulfil the demand for representative results due to the sample size of over 550 subjects while at the same time enabling meaningful classification of the persons surveyed. The primary reason for choosing this method in order to create types is that both for the language and for the neighbourhood dimension, there was no prior information about how to delimit types (e.g. thresholds for the individual variables).

At first a hierarchical, agglomerative cluster analysis was conducted based on the four or seven variables (= aspects) according to the Ward algorithm for each of the two dimensions. All of the eleven variables $(=4+7)$ are essentially of ordinal scale. Cluster analyses actually require variables of metric scale. In this case of evaluations, we assume that the differences between neighbouring evaluation categories for the individual interviewees are similar and can be set with the value 1 . This produces a metric character for the ordinal-scaled variables that suffices to be able to adequately conduct the cluster analyses.

In the following, the elbow criterion - a measure of the increase in information loss when iteratively forming clusters - will be used in particular as the stop criterion for the cluster analysis (= criterion to determine the number of clusters) (cf. e.g. Backhaus et al. 2008). The precise operationalisation is provided in the presentation of each of the analyses.

Then, the clustering result is optimised using the procedure of cluster centre analysis (= quick cluster) based on the target function "each object (= each respondent) should be in the cluster with a minimum distance between the objects and the cluster centroids (= most similar)." This kind of iterative optimisation method is suitable because the result of the hierarchical cluster analysis can depend on the order in which the objects enter the cluster analysis (Backhaus et al. 2008; Bahrenberg et al. 2008; Schendera 2008; Steinhausen/Langer 1977).

Based on the resultant clusters with similar assessments for the two dimensions German language competence and life in the neighbourhood, a contingency table analysis is used to verify the reciprocal effects with other variables of the survey. 
In addition to the general question of whether a significant correlation exists, the strength and the form of the correlations are also of interest.

\section{Dimensions of integration}

\subsection{Linguistic competence - a self-assessment}

\subsubsection{Overview of linguistic competence}

If, in theory, we assume that the assessment is symmetrical across the five evaluation categories (e.g. equal distribution), then we always reach a mean value of $\mu=3$. With regard to dispersion, such symmetrical distributions deliver different values depending on the type of distribution. The distributions that are of interest would be, for example, the equal distribution or the distribution that differs the most in the assessment. This would be the case if half of the respondents assess their skills with very good (1) and the other half with not at all (5) (U distribution). The following standard deviations result for these two distributions:

Equal distribution:

$$
\sigma^{2}=\frac{1}{n} \sum_{i=1}^{n}\left(x_{i}-\mu\right)^{2}=\frac{1}{n} \cdot\left(2 \cdot \frac{n}{5} \cdot 2^{2}+2 \cdot \frac{n}{5} \cdot 1^{2}+1 \cdot \frac{n}{5} \cdot 0^{2}\right)=2 \cdot \frac{1}{5}(4+1)=2 \rightarrow \sigma=\sqrt{2}=1.4142
$$

U distribution:

$$
\sigma^{2}=\frac{1}{n} \sum_{i=1}^{n}\left(x_{i}-\mu\right)^{2}=\frac{1}{n} \cdot n \cdot 2^{2}=2^{2} \rightarrow \sigma=2
$$

Table 2 shows the actual ascertained mean values and standard deviations as well as the minima and maxima. It demonstrates that all five of the evaluation categories are cited for all four aspects, but that the evaluation in the mean is always better than that achieved for a symmetrical distribution in the mean. It also illustrates that German writing skills are generally assessed considerably poorer than the other language skills (cf. also Vogel/Rinke 2008: 265).

The frequency distributions for the four linguistic aspects (Table 3) additionally show that for the two aspects listening and reading the distributions are relatively similar, with very high percentages in the assessment very good. At least two thirds of the respondents assess good or very good for both aspects. In speaking the percentages of at least a good assessment are quite high at almost 60 percent. By contrast, the percentages for the writing aspect are far more evenly distributed across the evaluation categories. Not even half of the respondents assess their German writing skills as at least good. 
Tab. 2: Parameters of the four linguistic aspects

\begin{tabular}{lcccc}
\hline & Minimum & Maximum & $\bar{X}$ & $S$ \\
\hline Speaking & 1 & 5 & 2.3494 & 1.2539 \\
Listening comprehension & 1 & 5 & 2.0924 & 1.1859 \\
Reading comprehension & 1 & 5 & 2.1128 & 1.2203 \\
Writing ability & 1 & 5 & 2.6987 & 1.2995 \\
\hline
\end{tabular}

Source: Authors' calculations

Tab. 3: Percentage frequencies of the four linguistic aspects

\begin{tabular}{lccccc}
\hline & $\begin{array}{c}\text { Very good } \\
(=1)\end{array}$ & $\begin{array}{c}\text { Good } \\
(=2)\end{array}$ & $\begin{array}{c}\text { Fair } \\
(=3)\end{array}$ & $\begin{array}{c}\text { A little } \\
(=4)\end{array}$ & $\begin{array}{c}\text { Not at all } \\
(=5)\end{array}$ \\
\hline Speaking & 33.64 & 25.32 & 19.41 & 15.71 & 5.91 \\
Listening comprehension & 41.59 & 26.99 & 17.01 & 9.43 & 4.99 \\
Reading comprehension & 43.07 & 23.84 & 16.82 & 11.28 & 4.99 \\
Writing ability & 23.11 & 24.58 & 21.63 & 20.70 & 9.98 \\
\hline
\end{tabular}

Source: Authors' calculations

\subsubsection{Linguistic competence clusters}

When carrying out the hierarchical cluster analysis the elbow phenomenon emerges in the step from five to four clusters, indicating a very large increase in information loss in this step. The loss is more than three times as large as the losses registered in the previous steps. Hence, a solution using five clusters is advisable. It remains manageable with regard to the number of clusters and the degree of generalisation (information loss) is not yet too advanced. All in all the clusters are - as the statistical parameters in Table 4 show - quite homogeneous. For example, the standard deviations within the clusters are far smaller than those for the entire sample shown in Table 2. In addition, there is a very clear ordinal arrangement of the clusters - as the mean values and the frequency diagrams for the clusters show -, namely from clusters whose members assess themselves in almost every aspect with very good to clusters in which the members concede themselves no language skills for almost every aspect. The sequence used in the following description of the clusters takes up this ordinal structure:

\section{Linguistic cluster 1:}

This cluster contains only respondents who assess all four aspects of their language skills mostly as very good and at least as good. 
Tab. 4: Statistical coefficients for the five linguistic clusters (L cluster 1 to L cluster 5)

\begin{tabular}{lccccc}
\hline & L cluster 1 & L cluster 2 & L cluster 3 & L cluster 4 & L cluster 5 \\
\hline $\begin{array}{l}\text { Mean values } \\
\quad \text { Speaking }\end{array}$ & 1.0115 & 2.0348 & 2.6330 & 3.7339 & 4.9118 \\
$\quad$ Listening comprehension & 1.0230 & 1.5304 & 2.2936 & 3.3486 & 4.7941 \\
$\quad$ Reading comprehension & 1.0230 & 1.4522 & 2.3394 & 3.5046 & 4.7353 \\
$\quad$ Writing ability & 1.2816 & 2.3217 & 3.2110 & 4.1468 & 4.9412 \\
Standard deviation & & & & & \\
$\quad$ Speaking & 0.1069 & 0.4575 & 0.5210 & 0.5026 & 0.2879 \\
$\quad$ Listening comprehension & 0.1503 & 0.5013 & 0.4773 & 0.5834 & 0.4104 \\
$\quad$ Reading comprehension & 0.1503 & 0.4999 & 0.4757 & 0.5548 & 0.4478 \\
$\quad$ Writing ability & 0.4511 & 0.5052 & 0.4920 & 0.4874 & 0.2388 \\
\hline
\end{tabular}

Source: Authors' calculations

Linguistic cluster 2:

The members of this cluster also give themselves pretty good assessments for the aspects of speaking, listening and reading (most at least good), whereby many still say very good for listening and reading. Poorer assessments than good occur only for the aspect writing to a larger extent. There are no more very good assessments for this aspect.

Linguistic cluster 3 :

The assessments chiefly range between good and fair. This cluster contains hardly any persons who give themselves a very good rating for any aspect; but there are also none who claim to have no language skills at all for one of the four aspects. The mean values show that the assessment of the two aspects listening and reading are still relatively positive; by contrast the value for the aspect speaking tends more in the direction of fair. This fair assessment is clearly not reached for the writing aspect.

\section{Linguistic cluster 4:}

This cluster contains no good assessments for the writing aspect. For all aspects the dominant assessment is fair or below fair. The assessment is generally somewhat more positive for the two aspects of listening and reading than for the two aspects speaking and writing, but it is distinctly poorer than for the previous three clusters.

\section{Linguistic cluster 5 :}

The cluster now only represents persons who place themselves in the negative area for all four linguistic aspects, thus ascribing themselves little or no skills. The focal point here, as the cluster mean values and the frequency diagram for the four aspects show, is clearly in the range of no skills at all. 
All in all, we reached the following results: There are two clusters whose members attest to linguistic competence in all four aspects that is very clearly above the mean. There are also two clusters whose members assess their linguistic competence clearly below fair. The fifth cluster (L cluster 3 ) holds a "middle" position ranging above fair linguistic competence for the two aspects listening and reading while the aspect of speaking is located slightly below and the aspect of writing distinctly below the assessment of "fair." The five clusters are not only ordinal, but for the assessment of the four linguistic aspects, they are clearly linear-hierarchically arranged as the structural web in Figure 1 demonstrates strikingly: the assessments for each aspect become consistently poorer from L cluster 1 to $L$ cluster 5 .

Fig. 1: $\quad$ Structural web of the linguistic clusters (based on mean values)

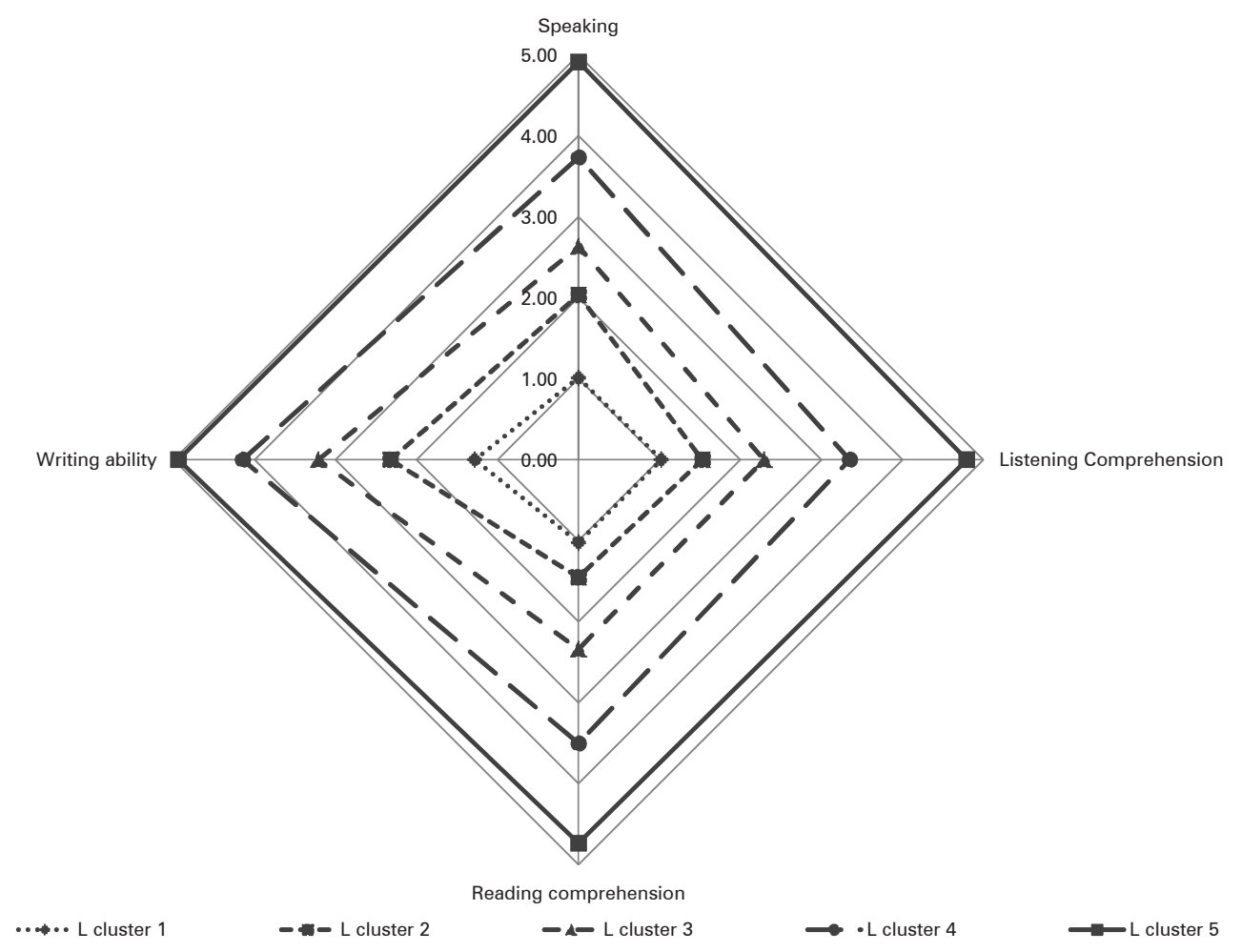

Source: own design

In view of the generally quite positive self-assessment of linguistic competence addressed above, it is not surprising that many people are represented in the "good" clusters (Table 5). Yet, it is notable that almost one third of the respondents categorise themselves in the "very good" range of linguistic competence. Only a little more than one fourth of the respondents classifies their own linguistic competence as "poor" at best, whereby only a little over 6 percent of the respondents attest that they have no German skills at all. 
Tab. 5: $\quad$ Linguistic clusters - frequencies

\begin{tabular}{lcc}
\hline & Absolute frequency & Percentage frequency \\
\hline L cluster 1 & 174 & 32.2 \\
L cluster 2 & 115 & 21.3 \\
L cluster 3 & 109 & 20.1 \\
L cluster 4 & 109 & 20.1 \\
L cluster 5 & 34 & 6.3 \\
Total & 541 & 100.0 \\
\hline
\end{tabular}

Source: Authors' calculations

\subsection{Neighbourhood - a self-assessment}

\subsubsection{Neighbourhood in an overview}

Along the lines of our considerations for the linguistic competence aspects, based on the four evaluation categories used here, the mean value for symmetrical distributions is always $\mu=2.5$. The standard deviations for the equal and $U$ distribution are then:

Equal distribution:

$$
\sigma^{2}=\frac{1}{n} \sum_{i=1}^{n}\left(x_{i}-\mu\right)^{2}=\frac{1}{n} \cdot\left(2 \cdot \frac{n}{4} \cdot 1.5^{2}+2 \cdot \frac{n}{4} \cdot 0.5^{2}\right)=2 \cdot \frac{1}{4}(2.25+0.25)=1.25 \rightarrow \sigma=\sqrt{1.25}=1.1180
$$

U distribution:

$$
\sigma^{2}=\frac{1}{n} \sum_{i=1}^{n}\left(x_{i}-\mu\right)^{2}=\frac{1}{n} \cdot n \cdot 1.5^{2}=1.5^{2} \rightarrow \sigma=1.5
$$

The information contained in Table 6 show that for all seven neighbourhood aspects, the respondents always named all of the four evaluation categories as responses. It is striking that only the three aspects acquainted with neighbours, recognise neighbours and help from neighbours were assessed more positively in the mean than would have for a symmetrical distribution. More negative mean assessments were cited for the other four aspects, which reveals that settling into the neighbourhood occurs only "aspect-by-aspect" and is/was not as intense (cf. Section 3.2.3).

This "aspect-by-aspect" breakdown of the assessment of settling into the neighbourhood also is shown by the percentage frequencies (Table 7). The values again confirm that the assessments for the various aspects are not, on the whole, very good. Only for the three aspects mentioned above, acquainted with neighbours, recognise neighbours and help from neighbours, there is a generally quite positive 
Tab. 6: $\quad$ Parameters for the seven neighbourhood aspects

\begin{tabular}{lcccc}
\hline & Minimum & Maximum & $\bar{X}$ & $S$ \\
\hline Many contacts & 1 & 4 & 2.6741 & 0.91031 \\
Acquainted with neighbours & 1 & 4 & 2.0567 & 1.03725 \\
Converse with neighbours & 1 & 4 & 2.6781 & 0.92500 \\
Greet the neighbours & 1 & 4 & 2.6457 & 0.93934 \\
Recognise neighbours & 1 & 4 & 1.8077 & 0.86951 \\
Invite neighbours & 1 & 4 & 2.9150 & 0.98922 \\
Help from neighbours & 1 & 4 & 2.0587 & 0.79207 \\
\hline
\end{tabular}

Source: Authors' calculations

Tab. 7: Percentage frequencies for the seven neighbourhood aspects

\begin{tabular}{lcccr}
\hline & $\begin{array}{c}\text { Very good } \\
(=1)\end{array}$ & $\begin{array}{c}\text { Good } \\
(=2)\end{array}$ & $\begin{array}{r}\text { Poor } \\
(=3)\end{array}$ & $\begin{array}{c}\text { Very poor } \\
(=4)\end{array}$ \\
\hline Many contacts & 10.73 & 30.77 & 38.87 & 19.64 \\
Acquainted with neighbours & 40.08 & 25.10 & 23.89 & 10.93 \\
Converse with neighbours & 10.93 & 31.17 & 37.04 & 20.85 \\
Greet the neighbours & 14.17 & 25.51 & 41.90 & 18.42 \\
Recognise neighbours & 45.14 & 33.00 & 17.81 & 4.05 \\
Invite neighbours & 10.32 & 22.47 & 32.59 & 34.62 \\
Help from neighbours & 21.05 & 59.51 & 11.94 & 7.49 \\
\hline
\end{tabular}

Source: Authors' calculations

assessment if approximately two thirds of respondents or more see these aspects positively. The majority of respondents assess the other four aspects in their neighbourhood rather negatively.

\subsubsection{Neighbourhood integration clusters}

The number of clusters could not be as clearly determined as for the linguistic clustering since the elbow phenomenon for information loss was not as distinct. However, when gathered in five clusters this did lead to a distinct loss of information. In this respect, we considered the 6 -cluster solution a good solution. The six neighbourhood clusters identified in this manner are quite homogeneous. Compared with the linguistic clusters, however, inner-cluster differences are greater. Although a rudimentary ordinal structure is also identifiable between the neighbourhood clusters, it is far weaker than among the linguistic clusters (cf. Table 8). The neighbourhood clusters can be described as follows: 
Tab. 8: $\quad$ Statistical coefficients for the six neighbourhood clusters ( $\mathrm{N}$ cluster 1 to $\mathrm{N}$ cluster 6)

\begin{tabular}{lcccccc}
\hline & N cluster 1 & N cluster 2 & N cluster 3 & N cluster 4 & N cluster 5 & N cluster 6 \\
\hline Mean values & & & & & & \\
$\quad$ Many contacts & 1.2917 & 2.0642 & 2.5205 & 2.7660 & 3.2385 & 3.8852 \\
Acquainted with neighbours & 1.0625 & 1.1193 & 2.1644 & 1.5106 & 2.8716 & 3.7705 \\
Converse with neighbours & 1.2500 & 2.1927 & 2.1644 & 3.1383 & 3.1009 & 3.8197 \\
Greet the neighbours & 1.3125 & 1.7798 & 2.6164 & 3.0957 & 3.2569 & 3.4918 \\
Recognise neighbours & 1.1042 & 1.0459 & 2.1233 & 1.4894 & 2.2477 & 3.0492 \\
Invite neighbours & 1.2292 & 2.4771 & 2.2603 & 3.5426 & 3.4404 & 3.9016 \\
Help from neighbours & 1.1042 & 1.8165 & 1.9178 & 2.0851 & 2.4587 & 2.6557 \\
Standard deviation & & & & & & \\
$\quad$ Many contacts & 0.5035 & 0.5490 & 0.6894 & 0.6788 & 0.4493 & 0.3214 \\
Acquainted with neighbours & 0.2446 & 0.3256 & 0.6239 & 0.5235 & 0.5110 & 0.4240 \\
Converse with neighbours & 0.4376 & 0.6006 & 0.5777 & 0.6493 & 0.5923 & 0.4285 \\
$\quad$ Greet the neighbours & 0.4684 & 0.5831 & 0.5684 & 0.6234 & 0.5838 & 0.5951 \\
Recognise neighbours & 0.4722 & 0.2102 & 0.6861 & 0.5631 & 0.6688 & 0.6690 \\
$\quad$ Invite neighbours & 0.4722 & 0.7403 & 0.6242 & 0.5421 & 0.5346 & 0.4361 \\
$\quad$ Help from neighbours & 0.3087 & 0.6111 & 0.3998 & 0.7429 & 0.7140 & 0.9641 \\
\hline
\end{tabular}

Source: Authors' calculations

Neighbourhood cluster 1:

This neighbourhood cluster is very clearly concentrated in the two positive evaluation categories, whereby the predominant majority of all respondents in this cluster assess all seven neighbourhood aspects very positively.

\section{Neighbourhood cluster 2:}

The respondents in this cluster also offer an altogether positive assessment, however, their assessments vary more for the aspects. For the two aspects acquainted with neighbours and recognise neighbours, the focus is clearly on a very positive assessment, but for all other aspects it lies only in the positive range with one exception: the invite neighbours aspect is strictly dichotomous in that roughly the same number of cluster members assess this aspect positively or negatively.

\section{Neighbourhood cluster 3:}

This cluster is highly characterised by the above-mentioned dichotomy for all seven aspects. Assessments go into the negative range for the two aspects many contacts and greet the neighbours. The other aspects tend to be seen rather positively, whereby the aspect help from neighbours in particular is notable for quite good evaluations. 


\section{Neighbourhood cluster 4:}

As for $\mathrm{N}$ cluster 2 , this cluster has again a very varying assessment structure, whereby the seven aspects in this cluster can be broken down into four different tendencies. Unlike N cluster 2, however, the assessments in this cluster are on the whole less positive. Also, the aspects acquainted with neighbours and recognise neighbours are quite positively assessed (positive to very positive). Also, the aspect help from neighbours is assessed positively (Tendency 2). Conversely, the aspects converse with neighbours and greet the neighbours are given clear minus points (Tendency 3). This tendency also includes the aspect many contacts, although a little more positively. The members of this cluster almost exclusively were negative (Tendency 4) about the aspect invite neighbours. All in all, the neighbourhood relationships remain at a consistently superficial level (cf. Section 3.2.3).

\section{Neighbourhood cluster 5:}

With the exception of the two aspects recognise neighbours and help from neighbours, which the majority of cluster members assessed positively, the by far largest number of members rated all other aspects at least negatively, in particular the assessment for invite neighbours.

\section{Neighbourhood cluster 6:}

With the exception of the aspect help from neighbours, for which at least some of the members of this cluster gave a positive assessment, otherwise almost only negative or very negative assessments were made. The four aspects many contacts, acquainted with neighbours, converse with neighbours and invite neighbours are particularly striking as more than three fourths of the members (up to over 90 percent) assess the situation in the neighbourhood as "very negative."

All in all, we can state the following results: The members of $\mathrm{N}$ cluster 1 rated all aspects of their neighbourhood as good to very good. On the opposite side, the members of cluster 6 assess all aspects of their neighbourhood situation negatively, whereby this poor assessment is only less stark for the aspect help from neighbours. The other four clusters align between these two extremes, however, without the clear linear-hierarchic arrangement that we saw in the linguistic clusters. Rather, the members in these "middle" clusters rate a number of aspects similarly while other aspects are assessed very divergently (cf. Fig. 2). For example, the members of the two clusters 4 and 5 rate the situation in their neighbourhoods for the aspects converse with neighbours, greet the neighbours, recognise neighbours and invite neighbours relatively similarly and the members of cluster 5 rate only the other three aspects many contacts, acquainted with neighbours and help from neighbours negatively. The members of the two $\mathrm{N}$ clusters 3 and 4 rate the two aspects many contacts and help from neighbours quite similarly, but their assessments for the other aspects are very different, whereby for the two aspects acquainted with neighbours and recognize neighbours the members of $\mathrm{N}$ cluster 4 see the situation more positively. It is the exact opposite for the aspects converse with neighbours, greet the neighbours and invite neighbours. 
Fig. 2: $\quad$ Structural web of neighbourhood clusters (based on mean values)

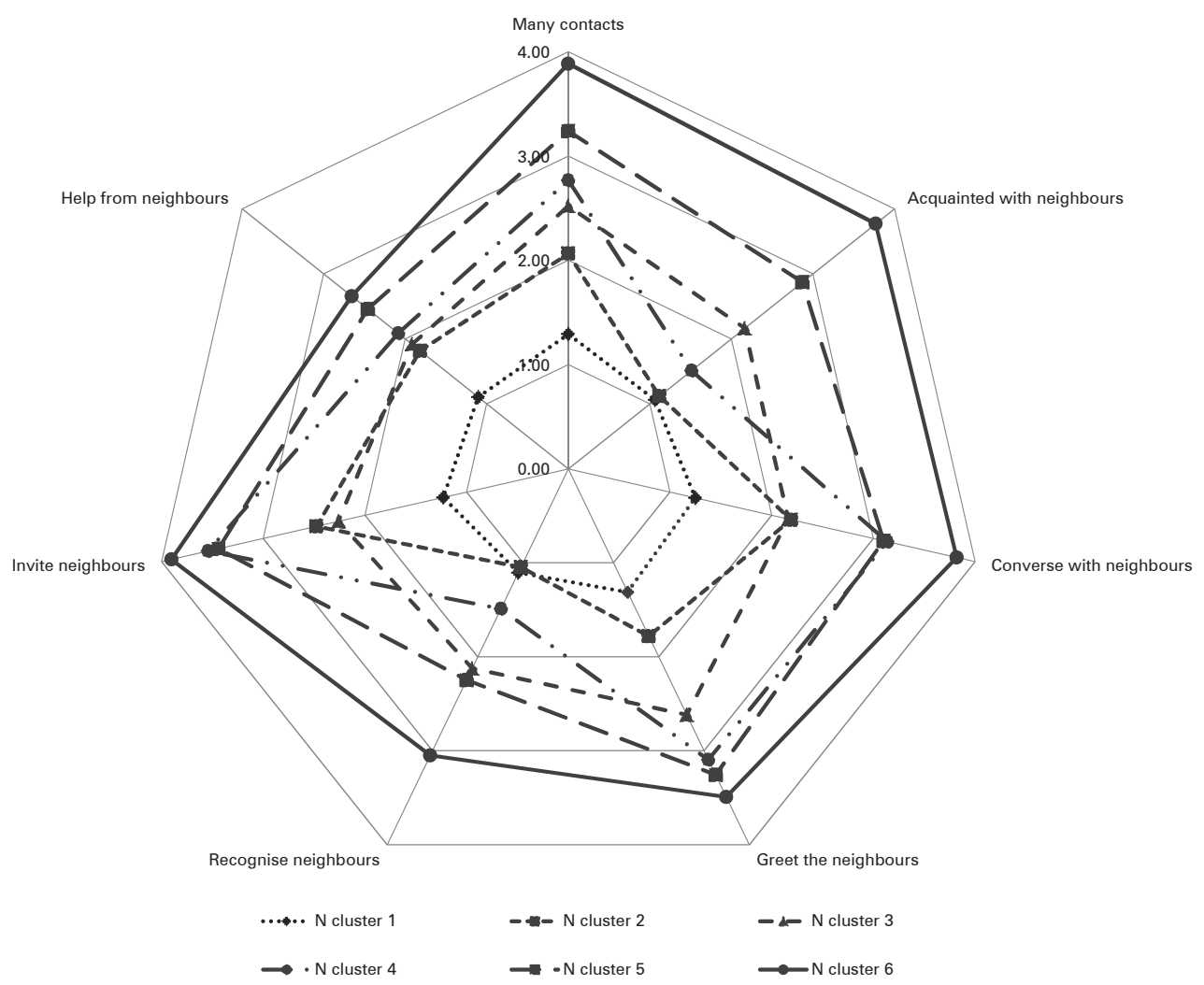

Source: own design

Given the overall rather less positive assessment of the neighbourhood situation, it is not surprising that not even one third of the respondents are represented in the two clusters whose members assess the neighbourhood situation as at least positive in almost all matters ( $\mathrm{N}$ clusters 1 and 2) (Table 9). Compared with the linguistic clusters, the distribution of respondents over the neighbourhood clusters is far more even, whereby the two "extreme" clusters (N cluster 1: positive; $\mathrm{N}$ cluster 6: negative) contain comparatively fewer members. All in all, these two clusters together contain less than one fourth of all respondents and more than three fourths are found in the "middle" clusters. 
Tab. 9: Neighbourhood clusters - frequencies

\begin{tabular}{lcc}
\hline & Absolute frequency & Percentage frequency \\
\hline N cluster 1 & 48 & 9.7 \\
N cluster 2 & 109 & 22.1 \\
N cluster 3 & 73 & 14.8 \\
N cluster 4 & 94 & 19.0 \\
N cluster 5 & 109 & 22.1 \\
N cluster 6 & 61 & 12.3 \\
Total & 494 & 100.0 \\
\hline
\end{tabular}

Source: Authors' calculations

\subsection{Language and neighbourhood in correlation with and subject to predictor variables}

\subsubsection{Correlation between language and neighbourhood}

The contingency table analysis proves that there is a highly significant correlation between linguistic competence and neighbourhood situation. At $C=0.3607$, the contingency coefficient is quite high. Table 10 shows that a disproportionately high number of members of the clusters with good linguistic competence rate their neighbourhood situation positively. By contrast, a disproportionately low number of members from the clusters with less linguistic competence are found in these positive neighbourhood clusters. Members with low linguistic competence rate their neighbourhood contacts as rather low.

Tab. 10: The correlation between linguistic clusters and neighbourhood clusters

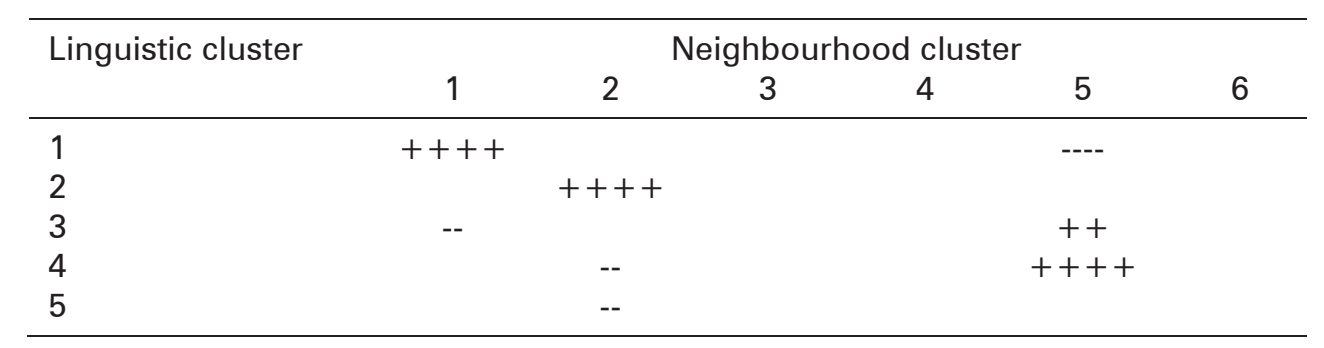

---- = very disproportionately low (= significant at the 1 percent level);

-- = disproportionately low (= significant at the 5 percent level);

$++=$ disproportionately high (= significant at the 5 percent level);

$++++=$ very disproportionately high (= significant at the 1 percent level)

Source: Authors' calculations 


\subsubsection{Hypotheses on the correlation between language and neighbourhood relationships with other predictor variables}

The clearly recognisable formation of linguistic and neighbourhood clusters addressed above leads us directly to the question of whether we can identify variables that are correlative with this cluster formation. These could be variables that can be interpreted as the result, for example, when good language skills help a person to feel at home in the city or variables that could account for this clustering. In the following, we will look at five spheres: personal individual and vocational variables, migration biography variables, environmental variables as well as variables that provide information on the assessment of the environment from the respondents' point of view. Note that the direction of the correlation is not always clearly identifiable. For instance, we assume that good linguistic competence makes closer neighbourhood ties more probable, but, on the other hand, we can also assume that closer neighbourhood ties promote good linguistic competence. In this respect we primarily focus on the term correlation without providing its direction. Against this background, we took the following variables from the survey and examined them for their correlation with the linguistic competence and/or neighbourhood situation:

\section{Personal individual variables}

- Gender: In numerous studies on immigration, gender is emphasised as a differentiating variable. However, there are no clear findings on whether the gender of academics influences the integration dimensions of neighbourhood and linguistic competence.

- Age: We could assume that younger persons, for example because of their greater flexibility, display greater potential for integration and accordingly that this group is more liable to assert they possess good linguistic competence and are better settled in their neighbourhood (cf. Section 3.2.2). However, it may also be that younger people do not require such an extent of linguistic competence in German because English is primarily spoken at work. We must also consider that the age variable can be correlated with two other variables: the duration of stay and the number of stays in Germany. If these two variables have an impact, this could lead to the correlation between integration and age being the exact opposite; namely that older people tend to be better integrated.

- Family/household structure: The family/household structure is of significance for integration in that we can assume that particularly if there are children in the household, this has a positive influence on linguistic competence and neighbourhood ties also among the adult members of the household. For example, these adults may come into closer contact with the neighbours via ties between their children (cf. Section 3.2.3).

Personal vocational variables

- Employment relationship: A permanent position will be a far greater incentive to improve one's German language skills and become more involved in the neighbourhood (cf. Section 3.2.2).

- Discipline: On the one hand, we could assume that the discipline of foreign university employees is in no way related to integration aspects. On the other hand, we could argue that foreign academics working in the humanities might be more 
interested in learning the German language while in disciplines such as the natural and economic sciences where English is increasingly the lingua franca there is far less necessity to "get involved" in learning German (cf. Section 3.2.2).

\section{Migration biography variables}

- Duration of stay: We assume that a longer stay has a positive effect on linguistic competence and the development of neighbourhood relationships (cf. Section 3.2.2).

- Number of stays: Like for the duration of stay variable, we assume that a greater number of stays also has positive effects on linguistic competence and the development of neighbourhood relationships.

- Origin: The origin is commonly considered a variable that influences integration, for instance in that persons from countries where the language is similar to that of the host country can more easily make social contacts (cf. Section 3.2.2). In this study, we asked the respondents to name their country of origin (nationality). As described in Section 4.1, these were then summarised in world regions. Because of statistical restrictions (sufficient number of cases), the following world regions were incorporated in the contingency table analyses: Western Europe, formerly socialistic Europe, predominantly Islamic countries, South Asia and East Asia.

- Transitional phase: Guests who consider their time in Germany only as a transitional phase will probably go to less "effort" to increase their competence in German and their settling into the neighbourhood than those who do not consider their stay in Germany a transitional phase (cf. Section 3.2.2).

\section{Environmental variables}

- City: We must ask whether the urban environment - in this case that of the university cities of Aachen, Bonn and Cologne - is correlated with the two dimensions language and neighbourhood, for instance in that the cities may be "open to integration" to different extents (cf. Section 3.2.2).

- Language course: We assume that attending German courses has a favourable effect on linguistic competence. In addition, it can provide better prerequisites for settling oneself in the neighbourhood. However, attending a German course cannot be assessed as a guarantee of good language skills. Furthermore, we must assume that persons who already possess good language skills from other contexts do not attend language courses.

\section{Reciprocal effects of linguistic competence and neighbourhood integration with the} assessment of the new environment

The variables discussed above describe actual situations of the survey subjects. The following variables refer, by contrast, to evaluations or assessments by the respondents with regard to a variety of spheres.

- Living in the city: How well a person likes living in the new city can certainly be influenced by very diverse factors. We could argue that linguistic competence and settling/integration in the neighbourhood can be considered good prerequisites for a good assessment.

- New friends and acquaintances in the city: Finding new friends and acquaintances in the host country certainly implies a significant extent of integration. We 
assume that good command of the German language and getting along well in the living environment promote this process.

- Treated like Germans: No doubt, good command of the German language is an important prerequisite for being treated like a "native." We also assume that a similar effect occurs along with good settling into the neighbourhood because one "simply is one of us."

- Feel comfortable: Feeling comfortable in the new environment is certainly promoted if one can communicate in the language of the destination country and when one has settled oneself in the neighbourhood. Likewise, we assume that this good feeling is also an incentive to improve one's language skills and become more involved in the neighbourhood.

- Exclusion: The experience of discrimination is no doubt an impediment to integration, but it is possible that a low degree of integration at the two dimensions of linguistic competence and living in the neighbourhood is also more liable to cause discrimination situations or feelings (cf. Section 3.2.2).

\subsubsection{Discussion of the results of the contingency table analysis}

The correlations resulting from the contingency table analyses for the cited variables with the two dimensions language and neighbourhood are listed in Table 11. When there are significant correlations between the two dimensions and the variables, they are (with the exception of the correlations linguistic competence - family/household structure) always highly significant. It is also notable that only the two variables gender and living in the city do not correlate significantly with the dimension language. For the neighbourhood dimension, there is a lack of significant correlations among far more variables. This applies to the variable gender as well as the migration biography variables number of stays and origin. Furthermore, no significant correlation can be identified for discipline, the two environment variables city and language course or the assessment variable feel comfortable. A comparison of the contingency coefficients additionally shows that in many cases, these are far higher for the correlations with the dimension language. This does not apply only to the two personal variables age and family/household structure, the variables transitional phase and employment relationship and for the assessment variable living in the city. For the latter we also find no correlation with linguistic competence, but only with the dimension neighbourhood. Therefore, the degree of linguistic competence apparently plays no direct role for the assessment whether living in the new city is positive, while more active involvement in the neighbourhood has a positive effect on the assessment of living in the city.

The analysis of the residuals for the variables largely shows the results anticipated in the hypotheses discussion above. We wish to look more closely both at the correlation between the family/household structure and the two integration dimensions and at the correlations between linguistic competence and the variables origin, discipline and city (we identified no correlations between these three variables and the dimension life in the neighbourhood). The results for the remaining variables are briefly portrayed in Table 12 . 
Tab. 11: Significant correlations (coefficients of contingency) between selected variables and linguistic and neighbourhood clusters

\begin{tabular}{lcc}
\hline Variable & Linguistic clusters & Neighbourhood clusters \\
\hline Personal individual variables & & 0.0872 \\
Gender & 0.1441 & $0.3292^{* * *}$ \\
Age & $0.2764^{* * *}$ & $0.4654^{* * *}$ \\
Family/household structure & $0.2345^{* *}$ & \\
Personal vocational variables & & $0.2875^{* * *}$ \\
Employment relationship & $0.2686^{* * *}$ & 0.2237 \\
Discipline & $0.3763^{* * *}$ & \\
Migration biography variables & & $0.3686^{* * *}$ \\
Duration of stay & $0.4456^{* * *}$ & 0.2423 \\
Number of stays & $0.3183^{* * *}$ & 0.2469 \\
Origin & $0.3709^{* * *}$ & $0.4090^{* * *}$ \\
Transitional phase & $0.3763^{* * *}$ & \\
Variables of the environment & & 0.2196 \\
City & $0.2532^{* * *}$ & 0.0910 \\
Language course & $0.3508^{* * *}$ & \\
Assessment of the new environment ${ }^{* *}$ & & $0.2703^{* * *}$ \\
Living in the city & 0.1010 & $0.3882^{* * *}$ \\
New friends and acquaintances in the city & $0.3182^{* * *}$ & $0.3458^{* * *}$ \\
Treated like Germans & $0.5007^{* * *}$ & 0.2137 \\
Feel comfortable in the city & $0.2454^{* * *}$ & $0.2773^{* * *}$ \\
Exclusion & $0.3950^{* * *}$ & \\
\hline
\end{tabular}

1 All of the assessment variables were originally coded - like the neighbourhood aspects - according to a scale of four assessments. The two poor assessment categories 3 and 4 were united to form one category for the contingency table analyses for statistical reasons (low numbers of cases).

** = significant at the 5 percent level (= significant);

*** = significant at the 1 percent level (= highly significant)

Source: Authors' calculations

Integration dimensions and family/household structure (cf. Table 13):

For the two integration dimensions linguistic competence and neighbourhood, we ascertained a distinct correlation in the anticipated direction whereby persons from households with children rate their linguistic competence higher and their neighbourhood integration better than persons living in households without children. We also noted that the correlation for the neighbourhood dimension is stronger than that of the language dimension (cf. Section 3.2.3). 
Tab. 12: Correlations between selected variables and the dimensions language and neighbourhood

\begin{tabular}{|c|c|c|}
\hline Variable & Language & Neighbourhood \\
\hline Gender & $\begin{array}{l}\text { We found no correlation between } \\
\text { linguistic competence and gender. }\end{array}$ & $\begin{array}{l}\text { We found no correlation between } \\
\text { neighbourhood integration and } \\
\text { gender. }\end{array}$ \\
\hline Age & $\begin{array}{l}\text { A disproportionately high number of } \\
\text { over } 50 \text {-year-olds attest to good lin- } \\
\text { guistic competence, while the under } \\
30 \text {-year-olds assess theirs dispropor- } \\
\text { tionately frequently as poor. }\end{array}$ & $\begin{array}{l}\text { The situation is similar to that for } \\
\text { linguistic competence: Older people } \\
\text { assess their ties to the neighbourhood } \\
\text { disproportionately frequently as posi- } \\
\text { tive; the younger consider their ties } \\
\text { more frequently as low. }\end{array}$ \\
\hline $\begin{array}{l}\text { Employment } \\
\text { relationship }\end{array}$ & $\begin{array}{l}\text { Persons with permanent positions } \\
\text { exhibit greater linguistic competence. }\end{array}$ & $\begin{array}{l}\text { Persons with permanent positions } \\
\text { are disproportionately frequently in } \\
\text { neighbourhood clusters characterised } \\
\text { by a more favourable neighbourhood } \\
\text { situation. }\end{array}$ \\
\hline Language course & $\begin{array}{l}\text { Persons who took one or more Ger- } \\
\text { man courses are more often mem- } \\
\text { bers in clusters with greater linguistic } \\
\text { competence. }\end{array}$ & $\begin{array}{l}\text { Language course attendance has no } \\
\text { direct effect on settling into the neigh- } \\
\text { bourhood. }\end{array}$ \\
\hline Duration of stay & $\begin{array}{l}\text { Linguistic competence increases with } \\
\text { the duration of stay. }\end{array}$ & $\begin{array}{l}\text { Persons who have lived for a good } \\
\text { while in Germany (more than } 5 \text { and } \\
\text { more than } 10 \text { years respectively) are } \\
\text { disproportionately more frequently in } \\
\text { the neighbourhood clusters with } \\
\text { generally quite positive assessments } \\
\text { (N cluster } 1 \text { and } 2 \text { ). }\end{array}$ \\
\hline Number of stays & $\begin{array}{l}\text { A disproportionately high number of } \\
\text { respondents who had never been to } \\
\text { Germany before frequently rate their } \\
\text { linguistic competence as poor and } \\
\text { only very rarely as very good. Those } \\
\text { who had been in Germany before } \\
\text { less frequently rated their linguistic } \\
\text { competence as poor, yet also not } \\
\text { necessarily as high. }\end{array}$ & There is no significant correlation. \\
\hline $\begin{array}{l}\text { Transitional } \\
\text { phase }\end{array}$ & $\begin{array}{l}\text { The linguistic clusters with high lin- } \\
\text { guistic competence contain a dispro- } \\
\text { portionately high number of mem- } \\
\text { bers who do not consider their stay a } \\
\text { transitional phase. Those who do, by } \\
\text { contrast, tend to gather in the clus- } \\
\text { ters with low linguistic competence. }\end{array}$ & $\begin{array}{l}\text { The correlation between neighbour- } \\
\text { hood clusters and assessment of the } \\
\text { stay as a transitional phase is similar } \\
\text { to that for the linguistic dimension. }\end{array}$ \\
\hline Living in the city & $\begin{array}{l}\text { We identified no correlation between } \\
\text { the assessment on whether the } \\
\text { respondents liked living in the city } \\
\text { and the assessment of their linguistic } \\
\text { competence. }\end{array}$ & $\begin{array}{l}\text { Persons who say that they have } \\
\text { settled well in the neighbourhood also } \\
\text { say that they like living in the city. }\end{array}$ \\
\hline
\end{tabular}


Tab. 12: Continuation

\begin{tabular}{|c|c|c|}
\hline Variable & Language & Neighbourhood \\
\hline $\begin{array}{l}\text { New friends and } \\
\text { acquaintances in } \\
\text { the city }\end{array}$ & $\begin{array}{l}\text { Foreign respondents with high lin- } \\
\text { guistic competence have found more } \\
\text { new friends and acquaintances in the } \\
\text { city. }\end{array}$ & $\begin{array}{l}\text { Respondents who have settled well } \\
\text { in the neighbourhood find more new } \\
\text { friends and acquaintances in the city. }\end{array}$ \\
\hline $\begin{array}{l}\text { Treated like } \\
\text { Germans }\end{array}$ & $\begin{array}{l}\text { High linguistic competence is far } \\
\text { more likely to lead to immigrants hav- } \\
\text { ing the feeling they are treated like } \\
\text { natives by the German population. }\end{array}$ & $\begin{array}{l}\text { Good integration in the neighbour- } \\
\text { hood leads immigrants to feel that } \\
\text { they are treated more often like } \\
\text { natives. }\end{array}$ \\
\hline Feel comfortable & $\begin{array}{l}\text { Persons with high linguistic compe- } \\
\text { tence report far more frequently that } \\
\text { they feel very comfortable where } \\
\text { they live. }\end{array}$ & $\begin{array}{l}\text { The quality of settling into the neigh- } \\
\text { bourhood has no direct effect on the } \\
\text { extent of feeling comfortable in the } \\
\text { chosen university city. This result is at } \\
\text { first surprising and may stem from the } \\
\text { fact that settling into the neighbour- } \\
\text { hood is not the first priority for the } \\
\text { stay and feeling comfortable. }\end{array}$ \\
\hline Exclusion & $\begin{array}{l}\text { A disproportionately high number } \\
\text { of members from clusters with low } \\
\text { linguistic competence have experi- } \\
\text { ences of exclusion. Only very few } \\
\text { of the respondents in high linguistic } \\
\text { competence clusters report such } \\
\text { experiences. }\end{array}$ & $\begin{array}{l}\text { Also, only a few people who live in a } \\
\text { positive neighbourhood situation re- } \\
\text { port of such experiences of exclusion. }\end{array}$ \\
\hline
\end{tabular}

Source: Authors' calculations

Tab. 13: Structure of the correlation: neighbourhood and family/household structure

\begin{tabular}{|c|c|c|c|c|c|c|}
\hline \multirow{2}{*}{$\begin{array}{l}\text { Family/ } \\
\text { household structure }\end{array}$} & \multicolumn{6}{|c|}{ Neighbourhood } \\
\hline & 1 & 2 & 3 & 4 & 5 & 6 \\
\hline Alone & & & & & & ++ \\
\hline With partner/relatives & & & & ++++ & & \\
\hline With children & ++++ & ++++ & & -- & -- & ---- \\
\hline
\end{tabular}

Source: Authors' calculations (Legend cf. Table 10)

Language and origin (cf. Table 14):

There is a very distinct correlation based on "cultural affinity." $L$ cluster 1 , the cluster with high linguistic competence, consisted of a very disproportionately high number of respondents from Western Europe. Persons of this region of origin are, by contrast, found in disproportionately low numbers in the clusters with low linguistic competence. Conversely, primarily respondents from Asian regions attest themselves very low language skills, while it was extremely rare to find persons from these countries with high linguistic competence. 
Tab. 14: Structure of the correlation: language and origin

\begin{tabular}{lccccc}
\hline Origin & \multicolumn{5}{c}{ Linguistic clusters } \\
& 1 & 2 & 3 & 4 & 5 \\
\hline Europe (western) & ++++ & & --- & \\
Europe (formerly socialistic) & & & & & \\
Predominantly Islamic countries & -- & & & & \\
South Asia & --- & & ++ & \\
East Asia & ---- & & ++++ & ++ \\
\hline
\end{tabular}

Source: Authors' calculations (Legend cf. Table 10)

Tab. 15: Structure of the correlation: language and discipline

\begin{tabular}{lccccc}
\hline Discipline & \multicolumn{5}{c}{ Linguistic clusters } \\
& 1 & 2 & 3 & 4 & 5 \\
\hline Natural sciences & ---- & -- & & ++++ & ++++ \\
Humanities & ++++ & & -- & --- & \\
Medicine & & & & -- \\
Engineering & & & & - \\
\hline
\end{tabular}

Source: Authors' calculations (Legend cf. Table 10)

Language and discipline (cf. Table 15):

In this case, in particular the exceedingly different structure of responses by university employees in the two disciplines natural sciences and humanities are notable. The humanities scholars very frequently rate themselves with very good linguistic competence and only very few consider it poor. Among the natural scientists it is exactly the opposite. The surveys conducted cannot measure the extent to which the academic field plays a role in this (language being a chief element of the humanities) or whether it is more due to the work environment (cf. Section 3.2.2). The engineers (exclusively working at the university in Aachen) on the whole lean more towards the humanities scholars; only a few of them consider their linguistic competence in German is poor. A closer look at the survey data does not explain this at first surprising finding with a high number of Dutch and Belgians due to the border location of Aachen in the Belgium-Germany-Netherlands triangle.

Language and city (cf. Table 16):

The highly significant correlation is caused by the dichotomy of the two cities Aachen and Bonn. Aachen has very few foreign university staff members who rate their language skills as poor. The situation in Bonn is the exact opposite where quite a large number of foreign staff of the university in Bonn rate their own linguistic competence as low and only very few as good or very good. One possible cause 
Tab. 16: Structure of the correlation: Language and city

\begin{tabular}{lccccc}
\hline City & \multicolumn{4}{c}{ Linguistic clusters } \\
& 1 & 2 & 3 & 4 & 5 \\
\hline Aachen & & & & ---- \\
Bonn & --- & -- & & +++ \\
Cologne & & & & \\
\hline
\end{tabular}

Source: Authors' calculations (Legend cf. Table 10)

is the different disciplines of the respondents in the three cities. In Bonn, far more natural scientists responded than in the two other cities. Moreover, many engineers were surveyed at the RWTH Aachen, a discipline that does not exist in the two other cities. As explained above, natural scientists tend to assess their linguistic competence as low and engineers tend to consider theirs better. In this respect, the result reflects a difference between the cities from a formal and statistical perspective; however, it is in content a result of the structure of respondents and confirms the differences in assessment by the disciplines. The above-discussed correlation between language and urban environment (cf. Section 3.2.2) cannot, therefore, be conclusively verified with the data surveyed and analysed here. This may, however, also be because the cities studied are neither distinctly small towns nor, in the other extreme, cosmopolitan cities.

\section{$6 \quad$ Summary and conclusions}

The integration of foreign immigrants has been an intense focus of both public discourse and research, but this noticeably is not the case for highly-skilled migrants. Hardly any validated, detailed findings have been made by research with the exception of a few studies of expatriates, a group that has a special place among highlyskilled migrants.

An analysis of existing literature on the subject of integration reveals that the process exhibits very diverse facets and the results are by no means always clearcut. However, it also shows that the cultural and the social dimensions play or can play a constitutive role in the shaping of integration. It turns out that the specific living conditions perceived by the immigrants in the cities have some influence on how integration is experienced. Against this background, this article deals with the integration processes of highly-skilled migrants in Germany, specifically of foreign academics. Based on a standardised survey of foreign academics at the universities in Aachen, Bonn and Cologne, the integration process was examined with regard to the following questions:

1. Are there clusters of foreign academics that differ from one another in the extent of their linguistic competence or their integration in the neighbourhood? How are clusters identified in this manner structured? 
2. Are there reciprocal effects between these two dimensions of integration or their structure and other variables?

Question 1: We identified five linguistic competence clusters on the basis of a cluster analysis. They are in themselves very homogeneous and can be ranked according to the quality of linguistic competence. This ranking of the clusters was equally identical with regard to all four individual aspects of linguistic competence. It therefore results in a clear linear-hierarchical structure. The clusters with greater linguistic competence have disproportionately high numbers. More than half of the respondents can be categorised in the two clusters with high linguistic competence and a mere six percent of the respondents say that their linguistic competence is very poor. The results are surprising in that the predominant majority only have temporary employment contracts. This indicates that although German language skills have lost significance in the working routine of German institutions of tertiary education, they continue to be necessary.

Six clusters were identified for the dimension of life in the neighbourhood through cluster analysis. These clusters are not as homogenous in structure as the linguistic competence clusters. Nonetheless, we were also able to detect a ranking; however the ranks were not as even with regard to all seven partial aspects, i.e. the structure is not as completely linear-hierarchical as for linguistic competence.

Question 2: 16 variables were chosen from the available survey. They can be categorised in the five attributes personal individual variables, migration biography, personal vocational variables, influence of the environment and assessment of the new environment. It is assumed that they correlate with the two integration dimensions of language and neighbourhood. We must emphasise that the direction of effect is not always clear. The correlations were verified using contingency table analyses.

As expected, there is a highly significant correlation between the two dimensions of integration, linguistic competence and life in the neighbourhood, in that disproportionately high numbers from the clusters with good linguistic competence assess their neighbourhood situation positively. By contrast, members with low linguistic competence tend to assess their degree of neighbourhood contacts as low.

It is striking that the significance of the correlations between the two integration dimensions and the 16 selected variables are usually - if they are significant at all - highly significant (1 percent significance level). Moreover, there are far more identifiable correlations with linguistic competence than with the neighbourhood. For linguistic competence we identified a significant correlation with 14 variables; only the variables gender and living in the city did not have this. For the neighbourhood, contrastingly, we only found significant correlations for nine variables. The results of the analysis generally reveal the results we anticipated based on the hypotheses discussion.

The correlations between the two dimensions linguistic competence and settling into the neighbourhood and the variable family/household structure (personal individual variables) as well as those of linguistic competence and the three variables national origin (migration biography variables), academic discipline (personal 
vocational variables) and city (environmental variables), which do not exhibit any significant correlations with the neighbourhood dimension, were examined in more detail with the following results:

a) The household situation of the respondents here in Germany has distinct effects on linguistic competence and on settling into the neighbourhood in that the respondents with children in the household attest to far better integration with regard to the two dimensions.

b) Foreign academics from Europe attest themselves good to very good language skills far more, while a disproportionately high number of academics from Asian countries place themselves in the clusters with low linguistic competence.

c) Also, natural scientists place themselves in clusters with low linguistic competence, while humanities scholars give themselves good to very good marks in German. We assume that one reason for this differentiation is their vocational routine since English is more frequently the language used to communicate in the natural sciences.

d) The highly significant correlation between city and linguistic competence results from the contrast between the two cities of Aachen and Bonn. In Aachen very few foreign university staff members rate their language skills as poor. The situation in Bonn is the exact opposite. We were unable to derive possible causes of this from the results of the survey.

We can state that the international mobility of academics exhibits some special features that differentiates them from other groups of highly qualified persons, in particular the institutional conditions of academic mobility sketched out above, which generally aim to support the mobility and integration of students and academics. This rarely exists in a comparative way for other professional groups.

All in all, the analyses of the group of highly-skilled migrants under study resulted in predominantly distinct and highly significant correlations between the dimensions cultural integration (linguistic competence) and social integration (neighbourhood relationships) on the one hand and a number of predictor variables on the other hand. These correlations reveal that there are a number of tangible starting points for improving co-existence (and therefore integration) of immigrants in their urban environment, such as language courses, duration of employment contracts or an improved welcoming culture at the university and in particular in the city.

\section{Acknowledgements}

In addition to the authors cited, the following colleagues worked on the project and are co-authors of this article: Stefanie Föbker, Marius Otto, Carmella Pfaffenbach, Günther Weiss and Claus-C. Wiegandt.

The authors would also like to thank two anonymous reviewers for valuable advice in the design of this article.

In February 2014, after the article has been finished and accepted for publication, Günter Thieme passed away. He was an esteemed colleague for all of us. Working with him was satisfying and his contributions in discussions were enlightening, always. 


\section{References}

Ackers, Louise 2010: Internationalisation and Equality. The Contribution of Short Stay Mobility to Progression in Science Careers. In: Recherches sociologiques et anthropologiques 41,1: 83-103.

Alexander von Humboldt-Stiftung 2012: Der Wettbewerb Welcome Centres 2010. Ergebnisse der dritten Runde [http://www.humboldt-foundation.de/pls/web/docs/F19345/ AvHWelcomfolder_2010_web.pdf, 10.12.2012].

Backhaus, Klaus; Erichson, Bernd; Plinke, Wulff; Weiber, Rolf 2008: Multivariate Analysemethoden. Eine anwendungsorientierte Einführung. 12 th Edition. Berlin u.a.: Springer.

Bauder, Harald 2012: The International Mobility of Academics: A Labour Market Perspective. In: International Migration Review, Early View (Online Version of Record published before inclusion in an issue), Accessed on 19 June 2013 [doi: 10.1111/j.14682435.2012.00783.x].

Bahrenberg, Gerhard; Giese, Ernst; Mevenkamp, Nils; Nipper, Josef 2008: Statistische

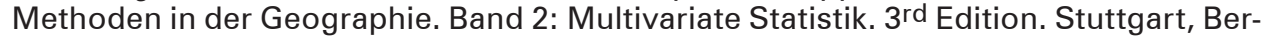
lin: Borntraeger.

Beaverstock, Jonathan V. 2005: Transnational Elites in the City: British Highly-Skilled Migrants in New York City's Financial District. In: Journal of Ethnic and Migration Studies 31,2: 245-268 [doi: 10.1080/1369183042000339918].

Braun, Michael; Recchi, Ettore 2008: Keine Grenzen, mehr Opportunitäten? Migration und soziale Mobilität innerhalb der EU. In: Berger, Peter A.; Weiss, Anja (Eds.): Transnationalisierung sozialer Ungleichheit. Wiesbaden: VS Verlag: 161-183.

BAMF (Bundesamt für Migration und Flüchtlinge) 2012: Neuer Aufenthaltstitel: Blaue Karte EU [http://www.bamf.de/SharedDocs/Meldungen/DE/2012/20120801-blauekarte-eu.html, 11.10.2012].

BMJ (Bundesministerium der Justiz) 2012: Gesetz über den Aufenthalt, die Erwerbstätigkeit und die Integration von Ausländern im Bundesgebiet (Aufenthaltsgesetz - AufenthG). Stand 2012 [http://www.gesetze-im-internet.de/bundesrecht/aufenthg_2004/ gesamt.pdf, 11.12.2012].

BMI (Bundesministerium des Innern) 2012: Migrationsbericht des Bundesamtes für Migration und Flüchtlinge im Auftrag der Bundesregierung. Migrationsbericht 2010. Berlin.

Cohen, Erik 1977: Expatriate Communities. In: Current Sociology 24,3: 5-90 [doi: 10.1177/001139217702400301].

Coles, Anne 2008: Making Multiple Migrations. The Life of British Diplomatic Families Overseas. In: Coles, Anne; Fechter, Anne-Meike (Eds.): Gender and family among transnational professionals. New York: Routledge: 125-148.

Conradson, David; Latham, Alan 2005: Friendship, networks and transnationality in a world city: Antipodean transmigrants in London. In: Journal of Ethnic and Migration Studies 31,2: 287-305 [doi: 10.1080/1369183042000339936].

DAAD (Deutscher Akademischer Austauschdienst) 2012: Wissenschaft weltoffen: Daten und Fakten zur Internationalität von Studium und Forschung in Deutschland. Bielefeld: W. Bertelsmann Verlag [http://www.wissenschaftweltoffen.de/publikation/ wiwe_2012_mit_links.pdf, 07.12.2012].

Espenshade, Thomas J.; Fu, Haishan 1997: An Analysis of English-Language Proficiency among U.S. Immigrants. In: American Sociological Review 62,2: 288-305. 
Esser, Hartmut 2006: Migration, Sprache und Integration. AKI-Forschungsbilanz 4. Berlin: Wissenschaftszentrum Berlin für Sozialforschung (WZB) Arbeitsstelle Interkulturelle Konflikte und gesellschaftliche Integration (AKI) [http://www2000.wzb.eu/alt/aki/ files/aki_forschungsbilanz_4.pdf, 03.01.2012].

EC (European Commission) 2008: Evidence on the main factors inhibiting mobility and career development of researchers. Brüssel [http://ec.europa.eu/euraxess/pdf/ research_policies/rindicate_final_report_2008_11_june_08_v4.pdf, 07.12.2012].

EP (European Parliament) 2009: Cross-Border Mobility of Young Researchers. Brüssel [http://old.certh.gr/libfiles/PDF/MOBIL-102-CROSS-BORDER-by-DG-IP-PD-A-in-EURPARL-POLICY-PP-35-Y-OCT-2009.pdf, 25.09.2012].

Fassmann, Heinz 2008: Entwicklungspotentiale einer zirkulären Migration in Europa. In: Geographische Rundschau 60,6: 20-25.

Favell, Adrian; Feldblum Miriam; Smith, Michael Peter 2006: The Human Face of Global Mobility: A Research Agenda. In: Smith, Michael Peter; Favell, Adrian (Eds.): The human face of global mobility. International highly skilled migration in Europe, North America and the Asia-Pacific. New Brunswick, NJ: Transaction Publishers: 1-25.

Findlay, Allan M. 1995: Skilled Transients: the Invisible Phenomenon? In: Cohen, Robin (Ed.): The Cambridge Survey of World Migration. Cambridge: Cambridge University Press: 515-522.

Fischer, Claude S. 1982: To dwell among friends. Personal networks in town and city. Chicago: University of Chicago Press.

Florida, Richard 2003: Cities and the Creative Class. In: City \& Community 2,1: 3-19 [doi: 10.1111/1540-6040.00034].

Föbker, Stefanie et al. 2010: At Home Abroad? The Situation of Highly Skilled Personnel in Germany. In: Geographische Rundschau International Edition 6,3: 64-69.

Föbker, Stefanie et al. 2011: Durchgangsstation oder neue Heimat - ein Beitrag zur Eingliederung von ausländischen hochqualifizierten Universitätsbeschäftigten in Aachen, Bonn und Köln. In: Berichte zur deutschen Landeskunde 85,4: 341-360.

Föbker, Stefanie; Pfaffenbach, Carmella; Temme, Daniela; Weiss, Günther 2014: Hemmnis oder Hilfe - die Rolle der Familie bei der Eingliederung ausländischer Hochqualifizierter in den lokalen Alltag. In: Geisen, Thomas; Studer, Tobias; Yildiz, Erol (Eds.): Migration, Familie und Gesellschaft. Beiträge zu Theorie, Kultur und Politik. Wiesbaden: Springer: 257-278.

Forrest, Ray 2008: Who cares about neighbourhoods? In: International Social Science Journal 59,191: 129-141 [doi: 10.1111/j.1468-2451.2009.00685.x].

Forrest, Ray; Kearns, Ade 2001: Social Cohesion, Social Capital and the Neighbourhood. In: Urban Studies 38,12: 2125-2143 [doi: 10.1080/00420980120087081].

Freund, Bodo 2000: Hochqualifizierte Migranten im Rhein-Main-Gebiet. In: Escher, Anton (Ed.): Ausländer in Deutschland. Probleme einer transkulturellen Gesellschaft aus geographischer Sicht. Mainz: Geographisches Institut, Johannes-Gutenberg-Universität: 85-98.

Gans, Paul 2011: Bevölkerung. Entwicklung und Demographie unserer Gesellschaft. Darmstadt: Primus Verlag.

Gestring, Norbert; Janßen, Andrea; Polat, Ayça 2006: Prozesse der Integration und Ausgrenzung. Türkische Migranten der zweiten Generation. Wiesbaden: VS Verlag.

Glebe, Günther 1986: Segregation and intra-urban mobility of a high status ethnic group: the case of the Japanese in Düsseldorf. In: Ethnic and Racial Studies 9,4: 461-483 [doi: 10.1080/01419870.1986.9993546]. 
Glebe, Günther 1997: Statushohe ausländische Migranten in Deutschland. In: Geographische Rundschau 49,7-8: 406-412.

Glorius, Birgit 2006: Transnationale Arbeitsmigration am Beispiel polnischer Arbeitsmigranten in Deutschland. In: Kulke, Elmar; Monheim, Heiner; Wittmann, Peter (Eds.): GrenzWerte. Tagungsbericht und wissenschaftliche Abhandlung: 55. Deutscher Geographentag Trier 2005. Berlin, Leipzig, Trier: DGfG: 141-149.

Glorius, Birgit 2007: Polnische Migranten in Leipzig. Eine transnationale Perspektive auf Migration und Integration. Empirischer Forschungsbericht. Hallesche Diskussionsbeiträge zur Wirtschafts- und Sozialgeographie 10. Halle: Selbstverlag des Instituts für Geowissenschaften, Martin-Luther-Universität Halle-Wittenberg [http://edoc.bibliothek. uni-halle.de/servlets/MCRFileNodeServlet/HALCoRe_derivate_00001638/Polnische Migranten_in_Leipzig,_empirische_Studie.pdf, 20.10.2012].

Grossetti, Miche/ 2005: Where do social relations come from? A study of personal networks in the Toulouse area of France. In: Social Networks 27,4: 289-300 [doi: 10.1016/j. socnet.2004.11.004].

Guest, Avery M.; Wierzbicki, Susan K. 1999: Social Ties at the Neighborhood Level: Two Decades of GSS Evidence. In: Urban Affairs Review 35,1: 92-111 [doi: 10.1177/10780879922184301].

Guth, Jessica 2007: Mobilität von Hochqualifizierten: Einflussfaktoren für die Zuwanderung von Nachwuchswissenschaftlern nach Deutschland. In: focus Migration Kurzdossier 6 [http://www.focus-migration.de/Mobilitaet_von_Hochq.1205.0.html, 12.12.2012].

Hardill, Irene 1998: Gender Perspectives on British Expatriate Work. In: Geoforum 29,3: 257-268.

Henning, Cecilia; Lieberg, Mats 1996: Strong ties or weak ties? Neighbourhood networks in a new perspective. In: Scandinavian Housing and Planning Research 13,1: 3-26 [doi: 10.1080/02815739608730394].

Hess, Barbara 2009: Zuwanderung von Hochqualifizierten aus Drittstaaten nach Deutschland. Ergebnisse einer schriftlichen Befragung. Working Paper der Forschungsgruppe des Bundesamtes für Migration und Flüchtlinge, 28. Nürnberg [http://www.bamf.de/SharedDocs/Anlagen/DE/Publikationen/WorkingPapers/wp28hochqualifizierte.pdf, 10.12.2012].

Hillier, Siân M. 2007: Americans in the Netherlands: Social Network Building and Maintenance through the use of Information Communication Technology and Associated Gender Effects. Unpublished master thesis, Utrecht [http://www.geo.uu.nl/mobilizing ICT/publications/Hillierthesischp01-5_revision5_1.pdf, 06.12.2011].

Hillmann, Felicitas 2010: New Geographies of Migration (Editorial). In: Die Erde 141,1-2: 1-13.

Hinte, Holger; Zimmermann, Klaus F. 2010: Agenda Zuwanderung: Zehn-Punkte-Aktionsplan des IZA. Gesteuerte Arbeitsmigration und bessere Integration. IZA Standpunkte 32. Bonn [http://ftp.iza.org/sp32.pdf, 06.03.2012].

Ilyes, Petra 2006: Transnationale Professionals. Aktuelle Sichtweisen auf die internationale Mobilität von Kompetenzen [http://publikationen.ub.uni-frankfurt.de/volltexte/ 2007/4403/pdf/ilyes_petra_mobilitaet.pdf, 11.12.2012].

Jöns, Heike 2006a: Grenzenlos mobil? Anmerkungen zur Bedeutung und Strukturierung zirkulärer Mobilität in den Wissenschaften. In: Kempter, Klaus; Meusburger, Peter; Boenicke; Rosemarie (Eds.): Bildung und Wissensgesellschaft. Berlin: Springer: 333362. 
Jöns, Heike 2006b: Internationale Mobilität von Wissen und Wissensproduzenten. In: Kulke, Elmar; Monheim, Heiner; Wittmann, Peter (Eds.): GrenzWerte. Tagungsbericht und wissenschaftliche Abhandlungen: 55. Deutscher Geographentag Trier 2005. Berlin, Leipzig, Trier: DGfG: 151-160.

Kearns, Ade; Parkinson, Michael 2001: The Significance of Neighbourhood. In: Urban Studies 38,12: 2103-2110 [doi: 10.1080/00420980120087063].

Kolb, Holger 2006: Internationale Mobilität von Hochqualifizierten - (k)ein Thema für die Migrationsforschung. In: Swiaczny, Frank; Haug, Sonja (Eds.): Neue Zuwanderergruppen in Deutschland. Materialien zur Bevölkerungswissenschaft 118. Wiesbaden: 159174 [http://www.bib-demografie.de/SharedDocs/Publikationen/DE/Materialien/118. pdf?_blob=publicationFile\&v $=3,10.12 .2012]$.

Mahroum, Sami 2000a: Highly skilled globetrotters: mapping the international migration of human capital. In: R\&D Management 30,1: 23-32 [doi: 10.1111/1467-9310.00154].

Mahroum, Sami 2000b: Scientific Mobility: An Agent of Scientific Expansion and Institutional Empowerment. In: Science Communication 21,4: 367-378 [doi: 10.1177/ 1075547000021004003].

Massey, Douglas S. et al. 1993: Theories of International Migration: A Review and Appraisal. In: Population and Development Review 19,3: 431-466.

Mau, Steffen; Mewes, Jan 2008: Ungleiche Transnationalisierung? Zur gruppenspezifischen Einbindung in transnationale Interaktionen. In: Berger, Peter A.; Weiss, Anja (Eds.): Transnationalisierung sozialer Ungleichheit. Wiesbaden: VS Verlag: 259-282.

Meier, Lars 2009: Das Einpassen in den Ort. Der Alltag deutscher Finanzmanager in London und Singapur. Bielefeld: transcript.

Nowicka, Magdalena 2006: "Feste Beziehung oder one-night stand?" Hochmobile und ihre Bindung zu Orten. In: Kreutzer, Florian; Roth, Silke (Eds.): Transnationale Karrieren. Biografien, Lebensführung und Mobilität. Wiesbaden: VS Verlag: 190-208.

Otto, Marius; Temme, Daniela; Weiss, Günther; Wiegandt, Claus-C. 2011: Das Einfinden ausländischer Universitätsmitarbeiter in die städtische Gesellschaft am Beispiel der Städte Aachen, Bonn und Köln. In: RaumPlanung 155: 78-82.

Otto, Marius; Temme, Daniela 2012: Deutsche Universitäten als Karrieresprungbrett? Zur Arbeits- und Lebenssituation ausländischer Wissenschaftlerinnen und Wissenschaftler in Aachen, Bonn und Köln. In: Deutsche Gesellschaft für Demographie (Ed.): Schrumpfend, alternd, bunter? Antworten auf den demographischen Wandel. DGD-Online-Publikation 01/2012. Bonn: 84-93 [http://www.demographie-online.de/ uploads/media/dgd-online_01_2012_Schrumpfend_alternd_bunter.pdf, 10.12.2012].

Pethe, Heike 2006: Internationale Migration hoch qualifizierter Arbeitskräfte. Die Greencard-Regelung in Deutschland. Wiesbaden: Deutscher Universitäts-Verlag/GWV Fachverlage $\mathrm{GmbH}$ Wiesbaden.

Portes, Alejandro; Böröcz, József 1989: Contemporary Immigration: Theoretical Perspectives on its Determinants and Modes of Incorporation. In: International Migration Review 23,3: 606-630.

Pries, Ludger 2001: Internationale Migration. Bielefeld: transcript.

Schendera, Christian F. G. 2008: Clusteranalyse mit SPSS. München: Oldenbourg.

Scott, Sam 2006: The Social Morphology of Skilled Migration: The Case of the British Middle Class in Paris. In: Journal of Ethnic and Migration Studies 32,7: 1105-1129 [doi: 10.1080/13691830600821802]. 
Statistisches Bundesamt 2007: Bildung und Kultur. Personal an Hochschulen 2006. Fachserie 11, Reihe 4.4 [https://www.destatis.de/GPStatistik/servlets/MCRFileNode Servlet/DEHeft_derivate_00006883/2110440067004.pdf, 07.12.2012].

Statistisches Bundesamt 2013a: Bevölkerung und Erwerbstätigkeit. Bevölkerung mit Migrationshintergrund - Ergebnisse des Mikrozensus 2012. Fachserie 1, Reihe 2.2 [https://www.destatis.de/DE/Publikationen/Thematisch/Bevoelkerung/Migration Integration/Migrationshintergrund2010220127004.pdf?__blob=publicationFile, 20.07.2014].

Statistisches Bundesamt 2013b: Bildung und Kultur. Personal an Hochschulen 2012. Fachserie 11, Reihe 4.4 [https://www.destatis.de/DE/Publikationen/Thematisch/ BildungForschungKultur/Hochschulen/PersonalHochschulen2110440127004.pdf, 20.07.2014].

Steinhausen, Detlef; Langer, Klaus 1977: Clusteranalyse. Einführung in Methoden und Verfahren der automatischen Klassifikation. Berlin: de Gruyter.

Thang, Leng Leng; Maclachlan, Elizabeth; Goda, Miho 2002: Expatriates on the margins - a study of Japanese woman working in Singapore. In: Geoforum 33,4: 539-551.

Todisco, Enrico; Brandi, Maria Carolina; Tattolo, Giovanna 2003: Skilled migration: a theoretical framework and the case of foreign researchers in Italy. In: FULGOR 1,3: 115-130.

Tremblay, Karine 2005: Academic Mobility and Immigration. In: Journal of Studies in International Education 9,3: 196-228 [doi: 10.1177/1028315305277618].

Tubergen, Frank van; Kalmijn, Matthijs 2005: Destination-Language Proficiency in Cross-National Perspective: A Study of Immigrant Groups in Nine Western Countries. In: American Journal of Sociology 110,5: 412-1457 [doi: 10.1086/428931].

Vogel, Dita; Rinke, Berit 2008: Sprache als der Schlüssel zur Integration? Theoretische Uberlegungen und qualitativ-empirische Befunde zu Sprachfunktionen im Integrationsprozess. In: Hillmann, Felicitas; Windzio, Michael (Eds.): Migration und städtischer Raum. Chancen und Risiken der Segregation und Integration. Opladen, Farmington Hills: Budrich UniPress: 261-277.

Voswinkel, Stephan; Kontos, Maria 2010: Probleme und Chancen der Beschäftigung hochqualifizierter Migrantinnen und Migranten. In: Sozialwissenschaften und Berufspraxis 33,2: 212-241.

Willis, Katie; Yeoh, Brenda 2002: Gendering transnational communities: a comparison of Singaporean and British migrants in China. In: Geoforum 33,4: 553-565.

White, Paul 1988: Skilled International Migrants and Urban Structure in Western Europe. In: Geoforum 19,4: 411-422 [doi:10.1016/S0016-7185(88)80013-7].

White, Paul; Hurdley, Louise 2003: International Migration and the Housing Market: Japanese Corporate Movers in London. In: Urban Studies 40,4: 687-706 [doi: 10.1080/0042098032000065254]. 
Daniela Imani, M.A. Geographisches Institut, Universität Bonn, Germany. E-Mail: imani@geographie.uni-bonn.de URL: http://www.wiegandt-stadtforschung.de/Arbeitsgruppe-Stadt-und-Regio.4.0.html Prof. Dr. Josef Nipper ( $₫)$. Geographisches Institut, Universität zu Köln, Germany. E-Mail: j.nipper@uni-koeln.de

URL: http://www.geographie.uni-koeln.de/contact.536.en.html

Prof. Dr. Günter Thieme †. Seminar für Geographie und ihre Didaktik, Universität zu Köln, Germany. 


\section{Comparative Population Studies}

WWW.comparativepopulationstudies.de

ISSN: 1869-8980 (Print) - 1869-8999 (Internet)

Published by / Herausgegeben von

Prof. Dr. Norbert F. Schneider

Federal Institute for Population Research

D-65180 Wiesbaden / Germany

Managing Editor /

Verantwortlicher Redakteur

Frank Swiaczny

Assistant Managing Editor /

Stellvertretende Redakteurin

Katrin Schiefer

Language \& Copy Editor (English) /

Lektorat \& Übersetzungen (englisch)

Amelie Franke

Copy Editor (German) /

Lektorat (deutsch)

Dr. Evelyn Grünheid

\section{Layout / Satz}

Beatriz Feiler-Fuchs

E-mail:cpos@bib.bund.de

\author{
Scientific Advisory Board / \\ Wissenschaftlicher Beirat \\ Paul Gans (Mannheim) \\ Johannes Huinink (Bremen) \\ Michaela Kreyenfeld (Rostock) \\ Marc Luy (Wien) \\ Clara H. Mulder (Groningen) \\ Notburga Ott (Bochum) \\ Peter Preisendörfer (Mainz) \\ Zsolt Spéder (Budapest)
}

\section{Board of Reviewers / Gutachterbeirat} Martin Abraham (Erlangen)

Laura Bernardi (Lausanne)

Hansjörg Bucher (Bonn)

Claudia Diehl (Konstanz)

Andreas Diekmann (Zürich)

Gabriele Doblhammer-Reiter (Rostock)

E.-Jürgen Flöthmann (Bielefeld)

Alexia Fürnkranz-Prskawetz (Wien)

Beat Fux (Salzburg)

Joshua Goldstein (Berkeley)

Karsten Hank (Köln)

Sonja Haug (Regensburg)

Aart C. Liefbroer (Den Haag)

Kurt Lüscher (Konstanz)

Dimiter Philipov (Wien)

Tomáš Sobotka (Wien)

Heike Trappe (Rostock) 